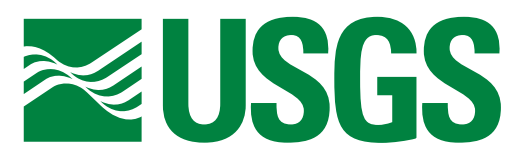

science for a changing world

\title{
Hurricane Isaac: Observations and Analysis of Coastal Change
}
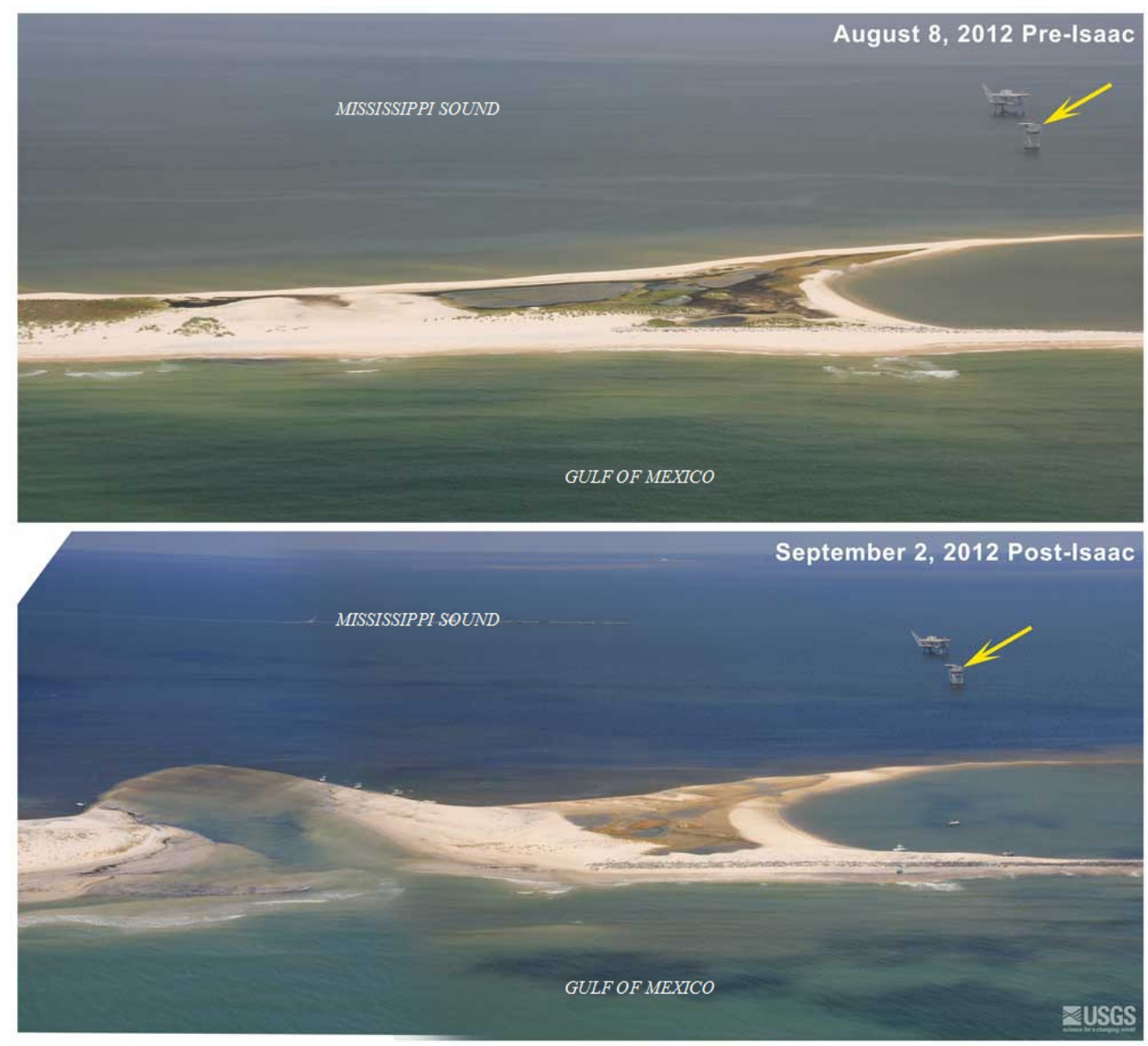

By Kristy K. Guy, Hilary F. Stockdon, Nathaniel G. Plant, Kara S. Doran, and Karen L.M. Morgan

Open-File Report 2013-1270

U.S. Department of the Interior U.S. Geological Survey 


\section{U.S. Department of the Interior SALLY JEWELL, Secretary}

\section{U.S. Geological Survey \\ Suzette M. Kimball, Acting Director}

U.S. Geological Survey, Reston, Virginia: 2013

For more information on the USGS-the Federal source for science about the Earth, its natural and living resources, natural hazards, and the environment-visit http://www.usgs.gov or call 1-888-ASK-USGS

For an overview of USGS information products, including maps, imagery, and publications, visit http://www.usgs.gov/pubprod

To order this and other USGS information products, visit http://store.usgs.gov

Any use of trade, firm, or product names is for descriptive purposes only and does not imply endorsement by the U.S. Government.

Although this information product, for the most part, is in the public domain, it also may contain copyrighted materials as noted in the text. Permission to reproduce copyrighted items must be secured from the copyright owner.

Cover photograph: Oblique aerial photographs of Dauphin Island, Alabama, from August 8, 2012 (top) and September 2, 2012 (bottom), 5 days after Hurricane Isaac made landfall (Photo credit: USGS).

Suggested citation:

Guy, K.K., Stockdon, H.F., Plant, N.G., Doran, K.S., and Morgan, K.L.M., 2013, Hurricane Isaac: Observations and Analysis of Coastal Change: U.S. Geological Survey Open-File Report 2013-1270, 21 p., http://dx.doi.org/10.3133/ofr20131270.

ISSN 2331-1258 (online) 


\section{Acknowledgments}

The USGS National Assessment of Coastal Change Hazards Project thanks James (Jamie) Young and others at Aerometric Inc. for conducting the lidar survey.

Many USGS scientists and support staff invested long hours toward analyzing the impact of Hurricane Isaac. We thank Mark Hansen, B.J. Reynolds, Nancy DeWitt, and Kyle Kelso who conducted the Chandeleur Islands ground survey; Dustin Kimbrow, Athena Clark, and Justin T. Minear who provided terrestrial lidar control data at Dauphin Island; Kristin Sopkin and Dave Thompson who processed data; James M. (Mike) Duncan and Timothy W. Saultz for lidar contracting; Felipe Dones-Cardona and Patti Hartsing for administrative support with lidar contracting; and Jolene Shirley who developed the Web page. 


\section{Contents}

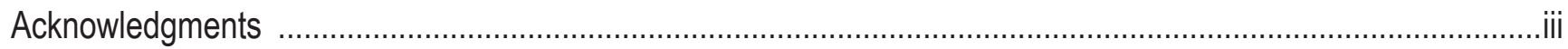

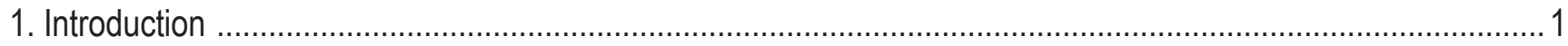

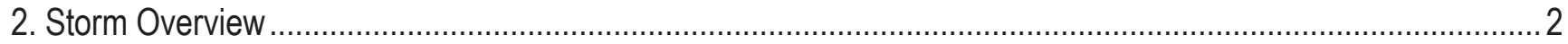

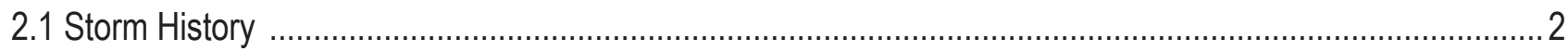

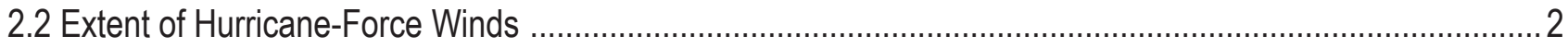

2.3 Offshore Wave Climate ....................................................................................................................

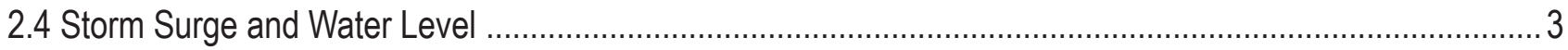

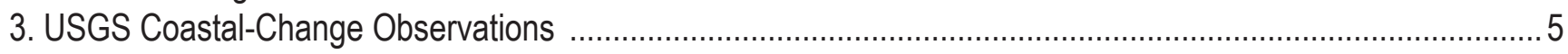

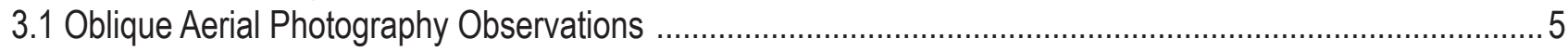

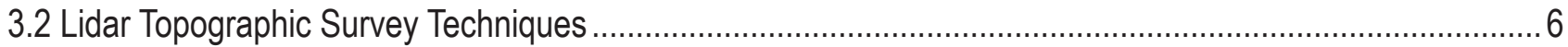

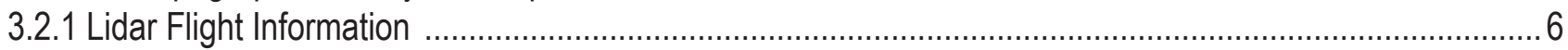

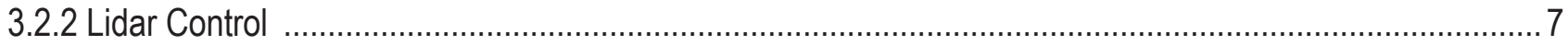

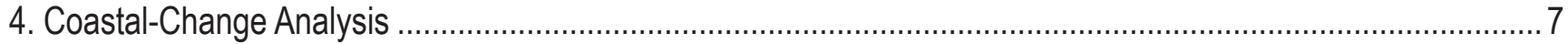

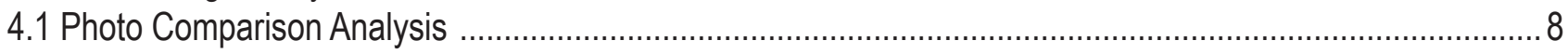

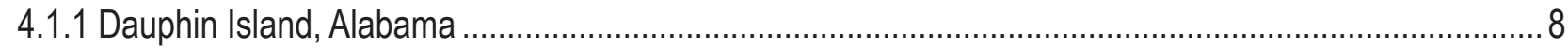

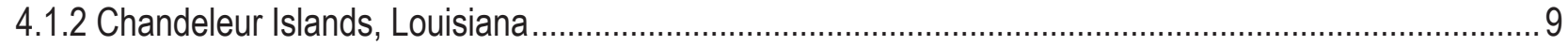

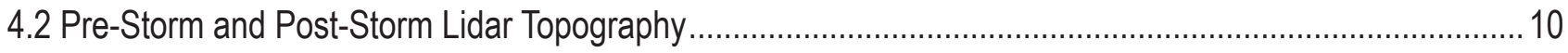

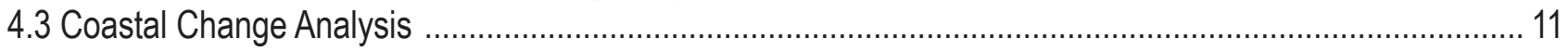

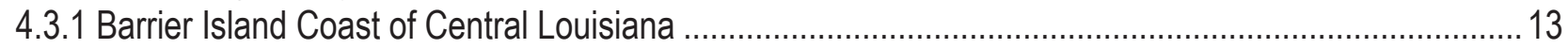

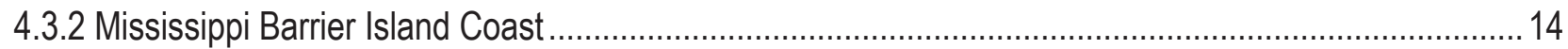

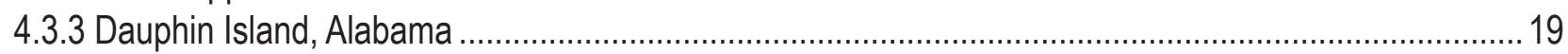

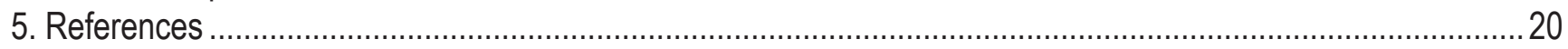

\section{Figures}

1. Track of Hurricane Isaac, locations of operating buoys 42001, 42012, and 42360, and Shell Beach tide gage, August 21-September 1, 2012.

2. Extent of Hurricane Isaac's maximum sustained winds categorized by tropical storm (yellow) and Category 1 hurricane (pink) strengths. The data were derived from estimates made by NOAA AOML. ..........................

3. Significant wave heights during the passage of Hurricane Isaac at buoys 42001,42012 , and 42360 .......... 4

4. Locations of post-Hurricane Isaac oblique aerial photography and lidar topography missions, ground-based control surveys, and GPS base stations.

5. Relation between Dauphin Island, Alabama, terrestrial lidar survey and September 2012 last-return airborne lidar survey.

6. Relation between Chandeleur Islands, Louisiana, ground survey and September 2012 last-return airborne lidar survey.

7. Map showing locations of photo-pair and lidar topography figures found in sections 4.1.1, 4.1.2, and 4.2.

8. Oblique aerial photographs of Dauphin Island, Alabama, from August 8, 2012 (top) and September 2, 2012 (bottom), 5 days after Hurricane Isaac made landfall. 
9. Oblique aerial photographs of Dauphin Island, Alabama, from August 8, 2012 (top) and September 2, 2012 (bottom), 5 days after Hurricane Isaac made landfall.

10. Oblique aerial photographs of Dauphin Island, Alabama, from August 8, 2012 (top) and September 2, 2012 (bottom), 5 days after Hurricane Isaac made landfall.

11. Oblique aerial photographs of a remnant of Chandeleur Islands, Louisiana, from August 8, 2012 (top) and September 2, 2012 (bottom), five days after Hurricane Isaac made landfall.

12. Oblique aerial photographs of Chandeleur Islands, Louisiana, from August 8, 2012 (top) and

September 2, 2012 (bottom), five days after Hurricane Isaac made landfall.

13. Elevation of Dauphin Island, Alabama, before (top) and after (middle) Hurricane Isaac and elevation change (bottom)

14. Elevation of Dauphin Island, Alabama, west of Katrina Cut, before (top) and after (middle) Hurricane Isaac and elevation change (bottom).

15. Elevation of Chandeleur Islands, Louisiana, before (top) and after (middle) Hurricane Isaac and elevation change (bottom)

16. Hurricane Isaac (A) dune elevation change, (B) shoreline change, and (C) beach volume change between September 2008 and September 2012 for the central Louisiana barrier island coast.

17. Hurricane Isaac (A) dune elevation change, (B) shoreline change, and (C) beach volume change between September 2008 and September 2012 for the state of Mississippi barrier island coast.

18. Hurricane Isaac (A) dune elevation change, (B) shoreline change, and (C) beach volume change between September 2008 and September 2012 for Dauphin Island.

\section{Tables}

1. Approximate locations of the National Geodetic Survey (NGS) Continuously Operating Reference Stations (CORS) and a temporary base station used for global positioning system (GPS) control during the September 5-10, 2012, lidar mission. 


\section{Conversion Factors}

\begin{tabular}{|c|c|c|}
\hline Multiply & By & To obtain \\
\hline \multicolumn{3}{|c|}{ Length } \\
\hline centimeter $(\mathrm{cm})$ & 0.394 & inch (in.) \\
\hline millimeter (mm) & 0.039 & inch (in.) \\
\hline meter $(\mathrm{m})$ & 3.281 & foot $(\mathrm{ft})$ \\
\hline kilometer (km) & 0.621 & mile (mi) \\
\hline meter $(\mathrm{m})$ & 1.094 & yard (yd) \\
\hline \multicolumn{3}{|c|}{ Area } \\
\hline square centimeter $(\mathrm{cm} 2)$ & 0.001 & square foot (ft2) \\
\hline square meter (m2) & 10.76 & square foot (ft2) \\
\hline square centimeter $(\mathrm{cm} 2)$ & 0.155 & square inch (ft2) \\
\hline \multicolumn{3}{|c|}{ Volume } \\
\hline liter $(\mathrm{L})$ & 33.82 & ounce, fluid (fl. oz) \\
\hline liter (L) & 2.113 & $\operatorname{pint}(\mathrm{pt})$ \\
\hline liter $(\mathrm{L})$ & 1.057 & quart (qt) \\
\hline liter (L) & 0.264 & gallon (gal) \\
\hline cubic meter (m3) & 264.2 & gallon (gal) \\
\hline cubic meter (m3) & 35.31 & cubic foot (ft3) \\
\hline cubic meter (m3) & 1.308 & cubic yard (yd3) \\
\hline \multicolumn{3}{|c|}{ Mass } \\
\hline $\operatorname{gram}(\mathrm{g})$ & 0.035 & ounce, avoirdupois (oz) \\
\hline kilogram (kg) & 2.205 & pound avoirdupois (lb) \\
\hline \multicolumn{3}{|l|}{ Pressure } \\
\hline kilopascal (kPa) & 0.010 & atmosphere, standard (atm) \\
\hline \multicolumn{3}{|c|}{ Energy } \\
\hline joule (J) & 0.000 & kilowatthour (kWh) \\
\hline \multicolumn{3}{|c|}{ Radioactivity } \\
\hline becquerel per liter $(\mathrm{Bq} / \mathrm{L})$ & 27.027 & picocurie per liter $(\mathrm{pCi} / \mathrm{L})$ \\
\hline
\end{tabular}

Temperature in degrees Celsius $\left({ }^{\circ} \mathrm{C}\right)$ may be converted to degrees Fahrenheit $\left({ }^{\circ} \mathrm{F}\right)$ as follows: ${ }^{\circ} \mathrm{F}=\left(1.8 \mathrm{x}^{\circ} \mathrm{C}\right)+32$

Temperature in degrees Fahrenheit $\left({ }^{\circ} \mathrm{F}\right)$ may be converted to degrees Celsius $\left({ }^{\circ} \mathrm{C}\right)$ as follows: ${ }^{\circ} \mathrm{C}=\left({ }^{\circ} \mathrm{F}-32\right) / 1.8$ 


\title{
Hurricane Isaac: Observations and Analysis of Coastal Change
}

\author{
By Kristy K. Guy, Hilary F. Stockdon, Nathaniel G. Plant, Kara S. Doran, and Karen L.M. Morgan
}

\section{Introduction}

Understanding storm-induced coastal change and forecasting these changes require knowledge of the physical processes associated with a storm and the geomorphology of the impacted coastline. The primary physical process of interest is sediment transport that is driven by waves, currents, and storm surge associated with storms. Storm surge, which is the rise in water level due to the wind, barometric pressure, and other factors, allows both waves and currents to impact parts of the coast not normally exposed to these processes.

Coastal geomorphology reflects the coastal changes associated with extreme-storm processes. Relevant geomorphic variables that are observable before and after storms include sand dune elevation, beach width, shoreline position, sediment grain size, and foreshore beach slope. These variables, in addition to hydrodynamic processes, can be used to quantify coastal change and are used to predict coastal vulnerability to storms (Stockdon and others, 2007).

The U.S. Geological Survey (USGS) National Assessment of Coastal Change Hazards (NACCH) project (http://coastal.er.usgs.gov/national-assessment) provides hazard information to those concerned about the Nation's coastlines, including residents of coastal areas, government agencies responsible for coastal management, and coastal researchers. Extreme-storm research is a component of the NACCH project (http://coastal.er.usgs.gov/hurricanes/) that includes development of predictive understanding, vulnerability assessments using models, and updated observations in response to specific storm events. In particular, observations were made to determine morphological changes associated with Hurricane Isaac, which made landfall in the United States first at Southwest Pass, at the mouth of the Mississippi River, at 0000 August 29, 2012 UTC (Coordinated Universal Time) and again, 8 hours later, west of Port Fourchon, Louisiana (Berg, 2013). Methods of observation included oblique aerial photography, airborne light detection and ranging (lidar) topographic surveys, and ground-based topographic surveys. This report documents data-collection efforts and presents qualitative and quantitative descriptions of hurricane-induced changes to the shoreline, beaches, dunes, and infrastructure in the region that was heavily impacted by Hurricane Isaac.

The report is divided into the following sections:

- Section 1: Introduction

- Section 2: Storm Overview, presents a synopsis of the storm, including meteorological evolution, wind speed impact area, wind-wave generation, and storm-surge extent and magnitudes.

- Section 3: Coastal-Change Observations, describes data-collection missions, including acquisition of oblique aerial photography and airborne lidar topographic surveys, in response to Hurricane Isaac.

- Section 4: Coastal-Change Analysis, describes data-analysis methods and observations of coastal change. 


\section{Storm Overview}

\subsection{Storm History}

Isaac was an active tropical weather system in the central tropical Atlantic Ocean, Caribbean Sea and Gulf of Mexico from August 21 to September 1, 2012 UTC (fig. 1). It became the ninth named storm of the 2012 hurricane season on August 21 at 1800 UTC about 835 kilometers (km) east of the Lesser Antilles. Isaac crossed the eastern Caribbean Sea, Haiti, Cuba, and the Gulf of Mexico as a tropical storm before strengthening to a Category 1 hurricane on the Saffir-Simpson Hurricane Wind Scale (Schott and others, 2012) on August 28 at 1200 UTC, about $140 \mathrm{~km}$ southeast of the mouth of the Mississippi River. It made landfall in Louisiana as a Category 1 hurricane at Southwest Pass, on the mouth of the Mississippi River, around 0000 UTC, August 29, with maximum sustained winds of 120-130 kilometers per hour $(\mathrm{km} / \mathrm{h})($ Berg, 2013).
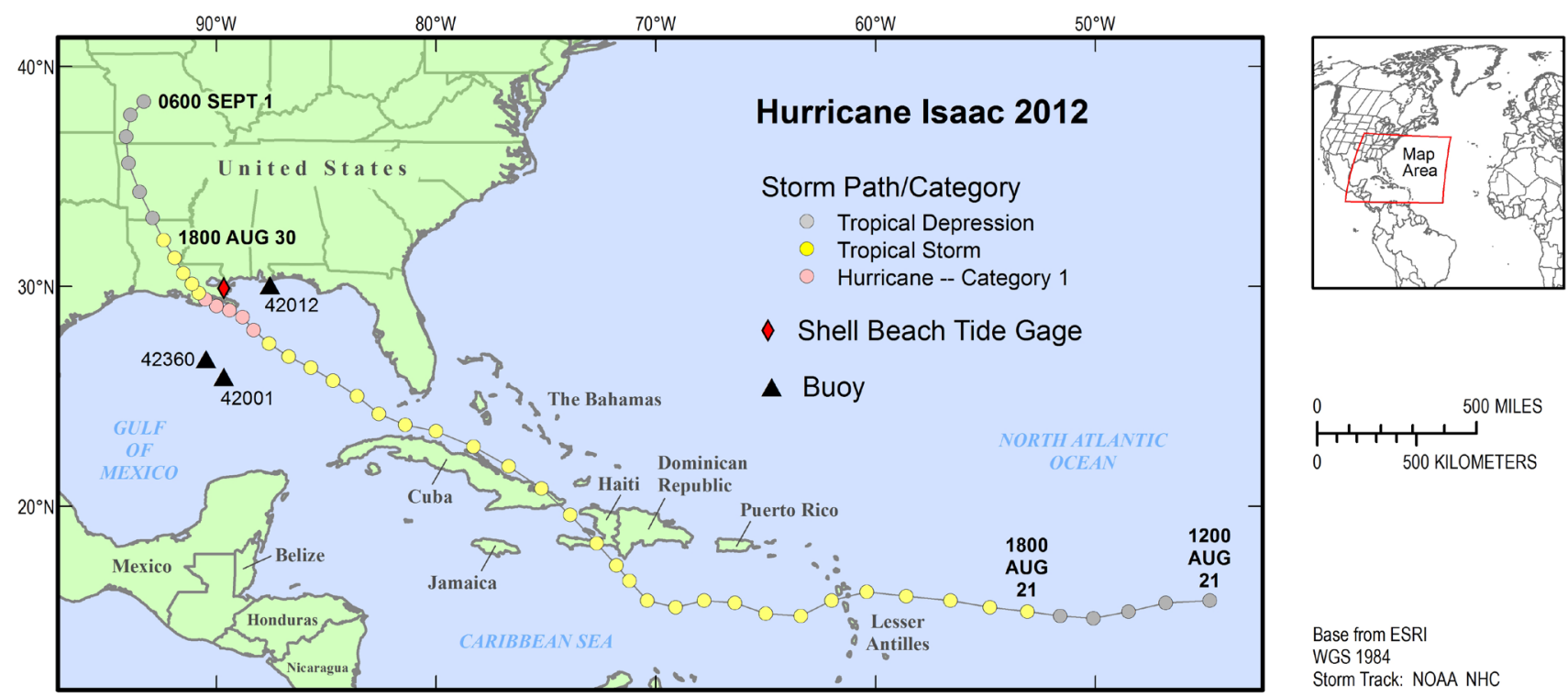

Figure 1. Track of Hurricane Isaac, locations of operating buoys 42001, 42012, and 42360, and Shell Beach tide gage, August 21-September 1, 2012.

\subsection{Extent of Hurricane-Force Winds}

Isaac's maximum sustained winds were measured at $120-130 \mathrm{~km} / \mathrm{h}$ at the Mississippi River with wind gusts of 139-152 km/h (Berg, 2013). Using methods described by Powell and others (1998), the National Oceanic and Atmospheric Administration's (NOAA) Atlantic Oceanographic and Meteorological Laboratory (AOML) Hurricane Research Division estimated sustained hurricane-force winds $(119 \mathrm{~km} / \mathrm{h}$ or greater) along approximately $215 \mathrm{~km}$ of the Mississippi River delta shoreline but did not extend inland (fig. 2). Tropical storm-force winds impacted the coastline from Marsh Island, on the central Louisiana coast, eastward to the Alabama/Florida border, extending inland into much of southeast Louisiana and parts of Mississippi. 

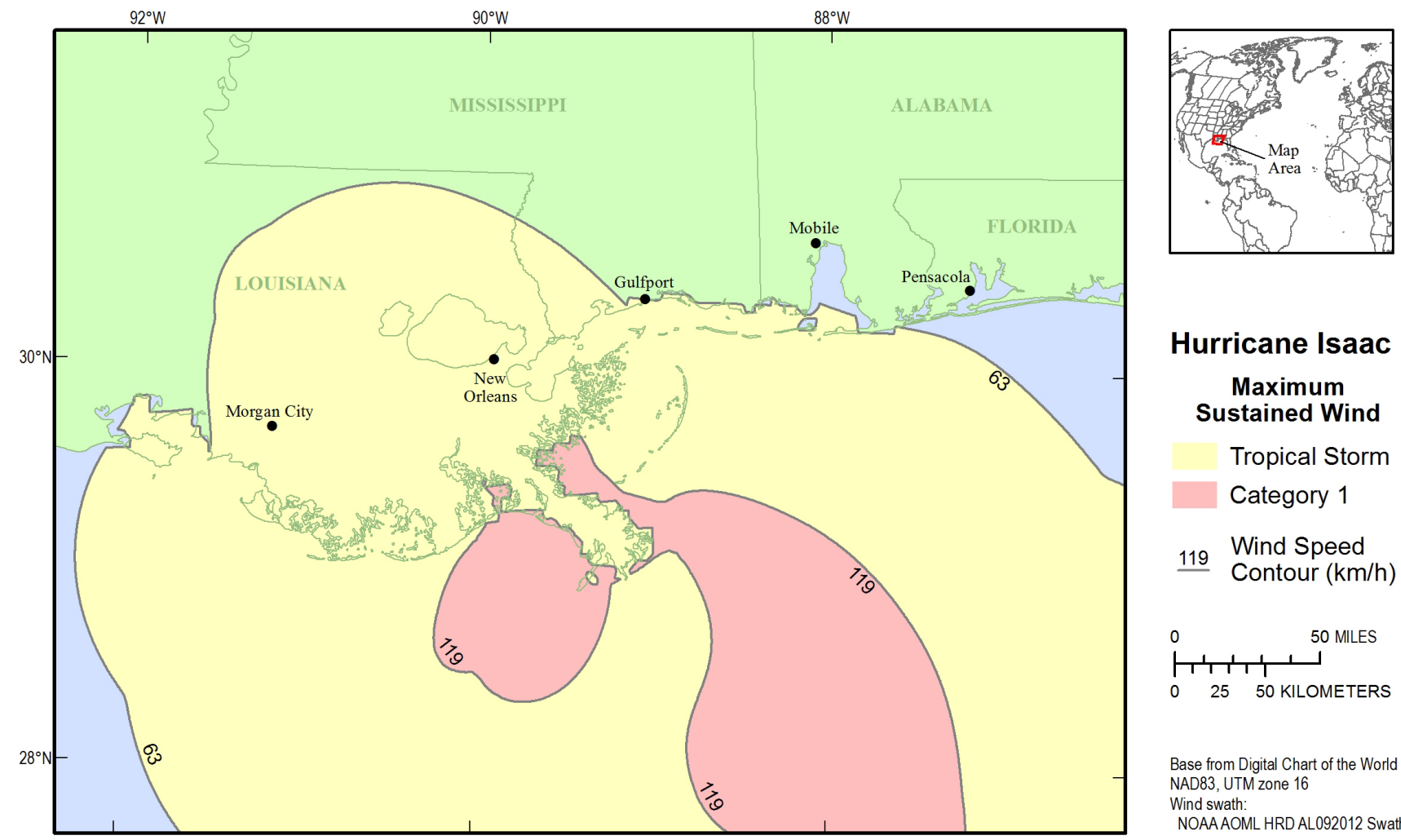

Hurricane Isaac

Maximum

Sustained Wind

Tropical Storm

Category 1

Wind Speed

119 Contour $(\mathrm{km} / \mathrm{h})$

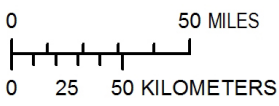

Base from Digital Chart of the World NAD83, UTM zone 16

Wind swath:
NOAAAOML HRD AL092012 Swath

Figure 2. Extent of Hurricane Isaac's maximum sustained winds categorized by tropical storm (yellow) and Category 1 hurricane (pink) strengths. The data were derived from estimates made by NOAAAOML.

\subsection{Offshore Wave Climate}

Several moored buoys measured heights and periods of waves generated by Hurricane Isaac. Hurricane Isaac passed near three buoys in the Gulf of Mexico as it approached landfall in Louisiana (fig. 1). NOAA National Data Buoy Center (NDBC) buoy 42012 is located approximately $80 \mathrm{~km}$ southeast of Mobile, Alabama, in 27.7 meters (m) of water. NOAA NDBC buoy 42001 is located approximately $335 \mathrm{~km}$ south of Southwest Pass (Mississippi River) in deep water (>2,500 m). PetrobrasU.S.A. operated buoy 42360 , which is located approximately $260 \mathrm{~km}$ south of Timbalier Island, Louisiana, in deep water $(>2,500 \mathrm{~m})$. The maximum significant wave heights recorded by these buoys was $5.9 \mathrm{~m}$ at buoy 42360 approximately 9 hours before first landfall, $4.7 \mathrm{~m}$ at buoy 42001 approximately 5 hours before first landfall, and $5.8 \mathrm{~m}$ at buoy 42012 approximately 3 hours before first landfall (National Data Buoy Center, undated) (fig. 3). All three buoys were outside the extent of hurricane force winds.

\subsection{Storm Surge and Water Level}

Measurements of maximum storm surge during Hurricane Isaac were made by coastal tide gages operated by NOAA. Storm surge elevations were observed from southeastern Florida to Louisiana. In Florida, the highest storm surge (observed water level minus predicted astronomical tide) was $1.049 \mathrm{~m}$ relative to mean lower low water and occurred in Apalachicola (station 8728690). In Alabama, the maximum storm surge was $1.411 \mathrm{~m}$, measured at Coast Guard Sector Mobile (station 8736897). As Isaac approached the Louisiana coast it slowed considerably, extending the time the coast was exposed to strong 


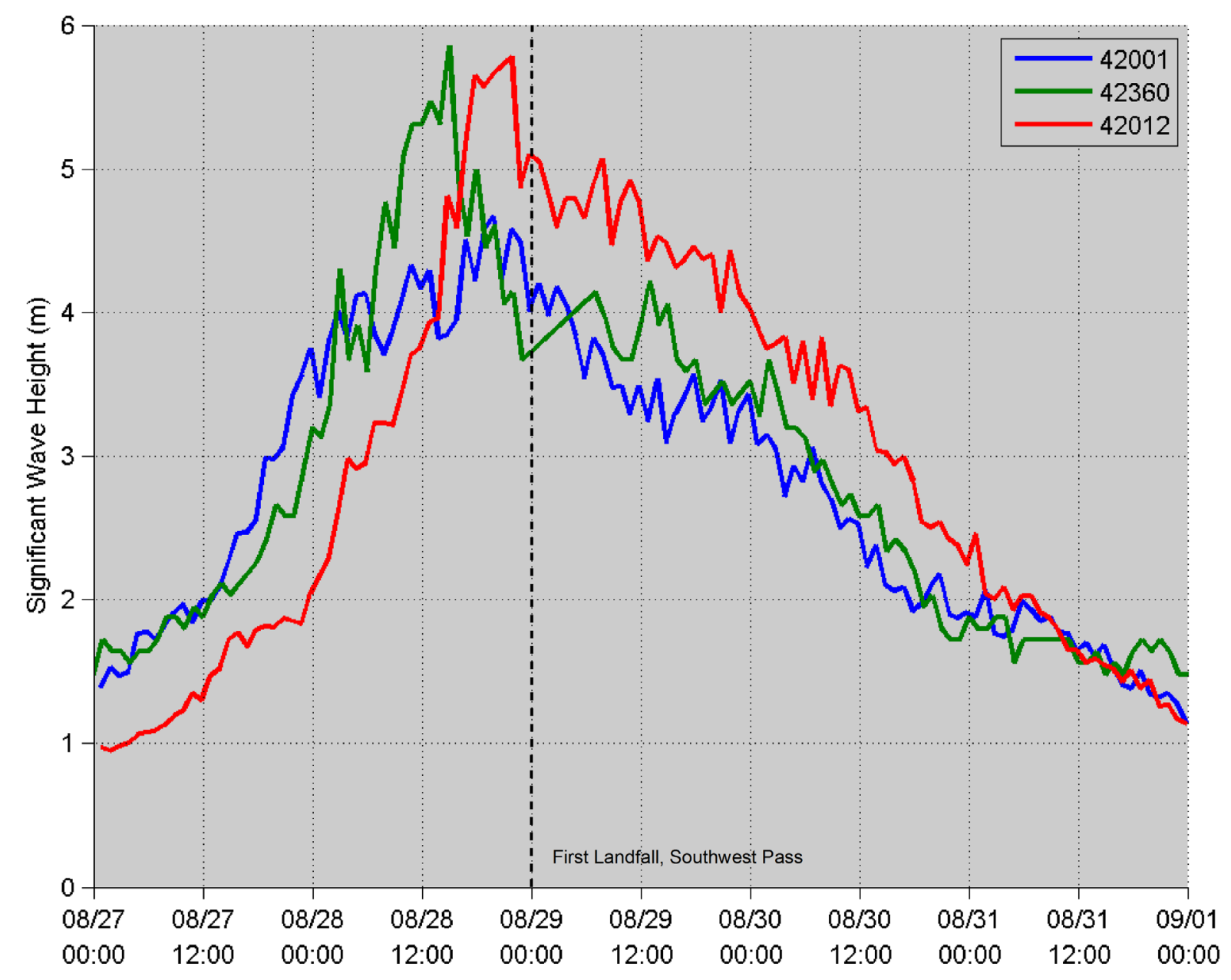

Figure 3. Significant wave heights during the passage of Hurricane Isaac at buoys 42001, 42012, and 42360.

winds and storm surge. The highest storm surge measured along the entire Gulf coast was $3.364 \mathrm{~m}$ at Shell Beach, Louisiana, located on the south shore of Lake Borgne near the Louisiana-Mississippi border (station 8761305). Prevailing offshore winds west of the storm track resulted in negative storm surge measurements as the storm made landfall. A negative storm surge of $-0.362 \mathrm{~m}$ was observed at LAWMA, Amerada Pass (station 8764227) and $-0.626 \mathrm{~m}$ at Freshwater Canal Locks (station 8766072) in Louisiana (Fanelli and Wolcott, 2012).

The USGS deployed temporary water-level sensors at 109 locations in Louisiana, Mississippi, and Alabama on August 27-28, 2012, immediately prior to landfall. Most were recovered within 7 days of landfall. The sensors recorded peak water-level elevations (astronomical tide plus storm surge) above North American Vertical Datum (NAVD 88). Example peak water-level elevations along the Mississippi and Alabama coast were $2.89 \mathrm{~m}$ at Mississippi Sound at Pass Christian Yacht Club (SSS-MS-HAR026WV), $2.04 \mathrm{~m}$ at the west side of Pascagoula Bay (SSS-MS-JAC-039WV), $2.26 \mathrm{~m}$ at Dauphin Island/ Bienville Boulevard (SSS-AL-MOB-002WV), and $1.79 \mathrm{~m}$ at Alabama Port (SSS-AL-MOB-006WV) (McCallum and others, 2012). 


\section{USGS Coastal-Change Observations}

The USGS NACCH project responded to Hurricane Isaac with the following data-collection missions (fig. 4):

- Post-storm oblique aerial photography (September 2-3, 2012)

- Post-storm airborne lidar topographic survey (September 5-10, 2012)

- Ground-based control surveys (September 3 and September 6, 2012)

The near-real-time responses of these efforts are documented at http://coastal.er.usgs.gov/ hurricanes/isaac/.
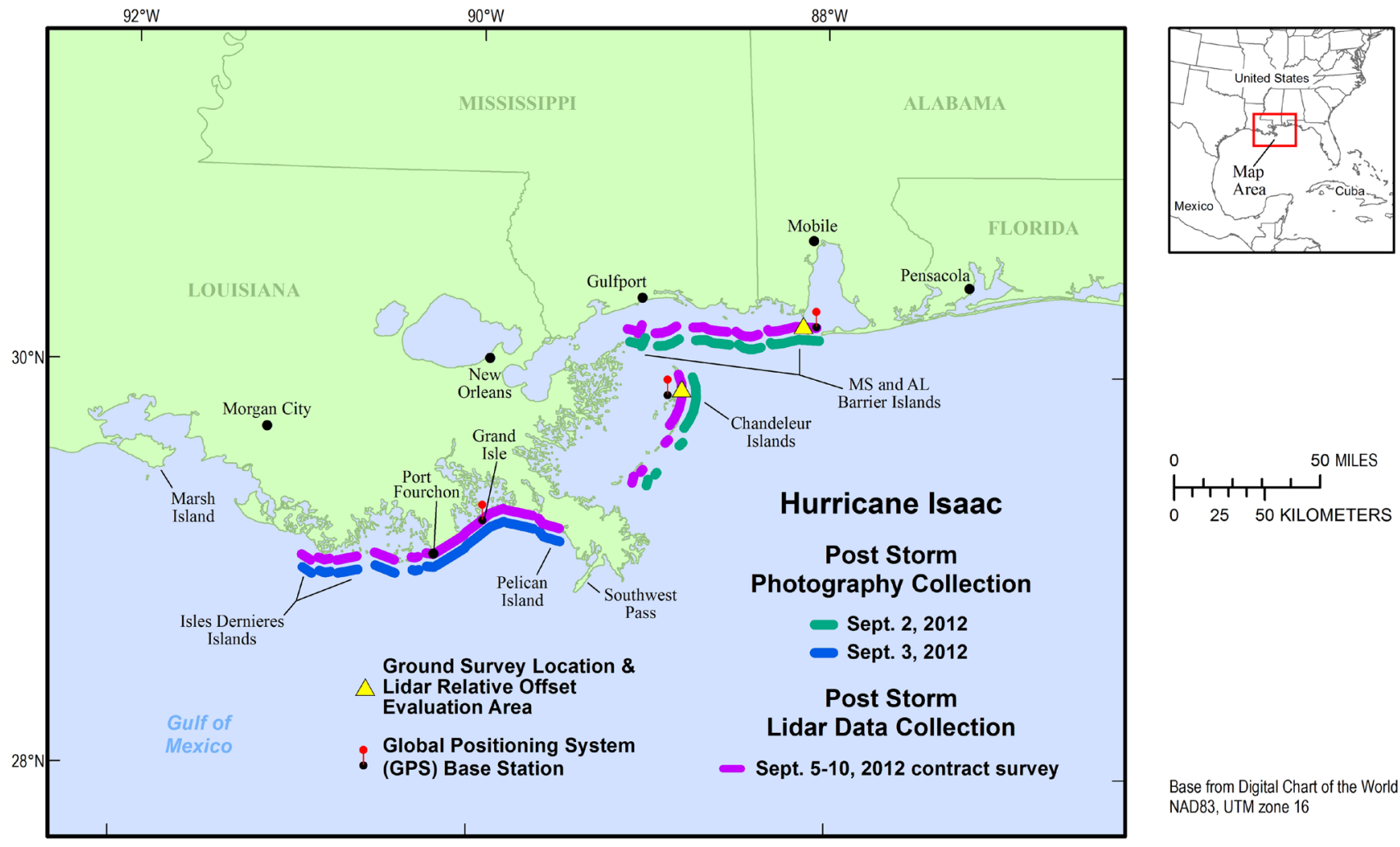

Base from Digital Chart of the World NAD83, UTM zone 16

Figure 4. Locations of post-Hurricane Isaac oblique aerial photography and lidar topography missions, ground-based control surveys, and GPS base stations.

\subsection{Oblique Aerial Photography Observations}

Whenever possible, the USGS collects oblique aerial photography of the coastline immediately before and after a storm makes landfall. The pre- and post-storm photographs are then compared to document where and how the storm impacted the coastline. When pre-storm missions are not flown immediately preceding landfall, photographs from earlier missions are used for comparison. These data are made available to emergency and coastal managers and others concerned with the storm's impact on the coast.

Post-Isaac oblique aerial photographs of the coastal areas near landfall were collected on September 2-3, 2012, starting 5 days after landfall. The photographs were shot with a Canon EOS Rebel T2i camera onboard a Cessna 172 aircraft. Every attempt was made to capture the entire targeted shoreline 
by overlapping the camera's range of view from one frame to the next. Approximately $270 \mathrm{~km}$ of shoreline was covered - from Isles Dernieres to Pelican Island in south-central Louisiana, the Chandeleur Islands in eastern Louisiana, and all of the Mississippi and Alabama barrier islands (fig. 4).

A pre-storm mission was not flown for Hurricane Isaac; however, a baseline (not storm related) mission was flown over the Chandeleur Islands, Louisiana, and all of the Mississippi and Alabama barrier islands on August 8, 2012, twenty days prior to landfall. Examples of pre- and post-storm photopairs for Dauphin Island, Alabama, and Chandeleur Islands, Louisiana, are found in Section 4.1.1 and 4.1.2, respectively.

\subsection{Lidar Topographic Survey Techniques}

High-resolution airborne lidar systems can map hundreds of kilometers of coast in a day with the density of elevation recordings exceeding one point per square meter. High point densities combined with sufficient horizontal and vertical accuracies allow for the creation of topographic and bathymetric digital elevation models (DEM) that show details of the coastal environment.

Lidar systems emit pulses of light that reflect off the Earth's surface, allowing the computation of elevation from the two-way transmission time. The high-frequency pulses are emitted from a laser that is mounted on a small aircraft. Aircraft movement is monitored by an inertial navigation unit, a global positioning system (GPS) unit, and tilt sensors. More complete descriptions of coastal lidar instruments and methods can be found in Brock and others (2002).

Lidar surveys receive positioning control using differential GPS, which requires a base-station receiver on the ground. The USGS sets up base stations near the area of hurricane impact, often augmenting NOAA's National Geodetic Survey (NGS) Continuously Operating Reference Stations (CORS). Additionally, because slowly varying positioning errors can corrupt the data (Sallenger and others, 2003), control points are surveyed for use in identifying and correcting these errors. Control points on surfaces that do not vary, such as roads or parking lots, can be obtained using ground-based surveying methods or by utilizing previous lidar surveys. Ground-based surveys performed on the beach surface are required to be synchronous with the lidar survey because of the likelihood for rapid and significant beach changes associated with the storm and the post-storm recovery period. Vertical accuracy of the lidar survey data is expected to be on the order of 10-20 centimeters (cm) (Sallenger and others, 2003), whereas the horizontal-position accuracy is on the order of $1 \mathrm{~m}$ (Nayegandhi and others, 2009).

After collection, the lidar data are processed to remove spurious data points and separate points into first- and last-return lidar products (Bonisteel and others, 2009), which are selected from the first and last backscatter to return to the sensor from the laser pulse. First-returns can be used to estimate canopy height in vegetated areas or rooftop height in developed areas, while last-returns can be used to estimate elevation of the bare-Earth surface under vegetation.

\subsubsection{Lidar Flight Information}

The USGS contracted a post-Isaac airborne lidar topographic survey of the Alabama, Mississippi, and Louisiana coastlines most affected by the storm (fig. 4). The mission was flown from September 5-10, 2012, and was completed 13 days after Isaac made landfall in Louisiana. An additional survey mission was conducted on October 11, 2012, to obtain additional data where the initial acquisition was insufficient. A total of 12 flights were made. Approximately $230 \mathrm{~km}$ of coastline was flown, including 
the islands of Dauphin, Petit Bois, Horn, Ship, Cat, Chandleur, Breton, Pelican, Gilmore, Lanaux, Bastian, Grand Terre, Grand Isle, Elmers, East Timbalier, Timbalier, and Isles Dernieres and the mainland coast near Port Fourchon. More than 620 million data points were collected.

\subsubsection{Lidar Control}

Airborne positioning during the lidar mission was based on two CORS located on Dauphin Island, Alabama, and Grand Island, Louisiana, plus a temporary base station set up on Chandeleur Islands, Louisiana (fig. 4; table 1). Geodetic control points were collected in a small area on Chandeleur Islands and used to assess the vertical accuracy of the lidar data.

Table 1. Approximate locations of the National Geodetic Survey (NGS) Continuously Operating Reference Stations (CORS) and a temporary base station used for global positioning system (GPS) control during the September 5-10, 2012, lidar mission.

\begin{tabular}{llll}
\hline Station ID & Location & Latitude & Longitude \\
\hline CORS ALDI & Dauphin Island, AL & $30^{\circ} 14^{\prime} 57^{\prime \prime}$ & $-88^{\circ} 04^{\prime} 04^{\prime \prime}$ \\
CORS GRIS & Grand Island, LA & $29^{\circ} 15^{\prime} 56^{\prime \prime}$ & $-89^{\circ} 57^{\prime} 26^{\prime \prime}$ \\
TMRK (temporary) & Chandeleur Islands, LA & $29^{\circ} 57^{\prime} 02^{\prime \prime}$ & $-88^{\circ} 49^{\prime} 33^{\prime \prime}$ \\
\hline
\end{tabular}

\subsubsection{Lidar Quality}

Vertical accuracy of the post-storm lidar was evaluated against ground-based surveys (fig. 4) conducted by the USGS on Dauphin Island, Alabama, September 3, 2012, and Chandeleur Islands, Louisiana, September 6, 2012.

Quality-control grids were interpolated from last-return lidar data collected at these ground-survey locations. Interpolation to the $2 \times 2-\mathrm{m}$ grid domain included applying a smoothing filter that removed short-scale variability and determined the degree to which residual noise had been removed (Plant and others, 2002). Elevations at grid points that received too few observations were removed to reduce system noise.

The Dauphin Island ground survey used a terrestrial lidar instrument mounted to a truck. The survey points were interpolated to a $2 \times 2-\mathrm{m}$ grid to match the airborne lidar grid resolution. The offset between the gridded ground survey and the September 5-10, 2012, last-return gridded lidar data is $0.27 \mathrm{~m}( \pm 0.32 \mathrm{~m})$ (fig. 5). The lidar data for Mississippi and Alabama were adjusted by subtracting $0.27 \mathrm{~m}$ before extracting morphologic features.

The Chandeleur Islands ground survey was conducted simultaneously with the lidar flight. A kinematic GPS mounted on a buggy was used to survey 90,000 square meters $\left(\mathrm{m}^{2}\right)$ of the low-lying beach and marsh. The survey points were interpolated to a $2 \times 2-m$ grid to match the lidar grid resolution. The offset between the gridded ground survey and the last-return gridded lidar data is $0.007 \mathrm{~m}( \pm 0.072 \mathrm{~m})$, well within the expected vertical error of the lidar data (fig. 6).

\section{Coastal-Change Analysis}

Pre-storm and post-storm photographs were compared to identify examples of coastal changes that span the range of responses to the hurricane conditions. Pre-storm and post-storm lidar topographic surveys were compared to quantify the spatial extent and magnitude of these coastal changes including estimates of changes in dune height, shoreline position, and subaerial sediment volume. 


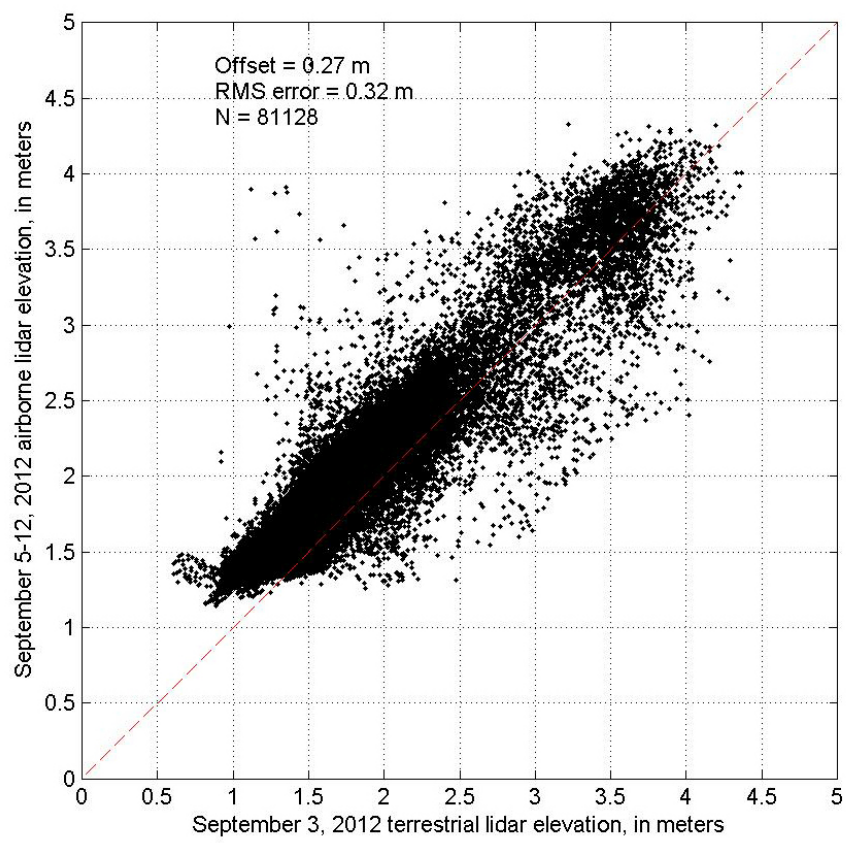

Figure 5. Relation between Dauphin Island, Alabama, terrestrial lidar survey and September 2012 last-return airborne lidar survey.

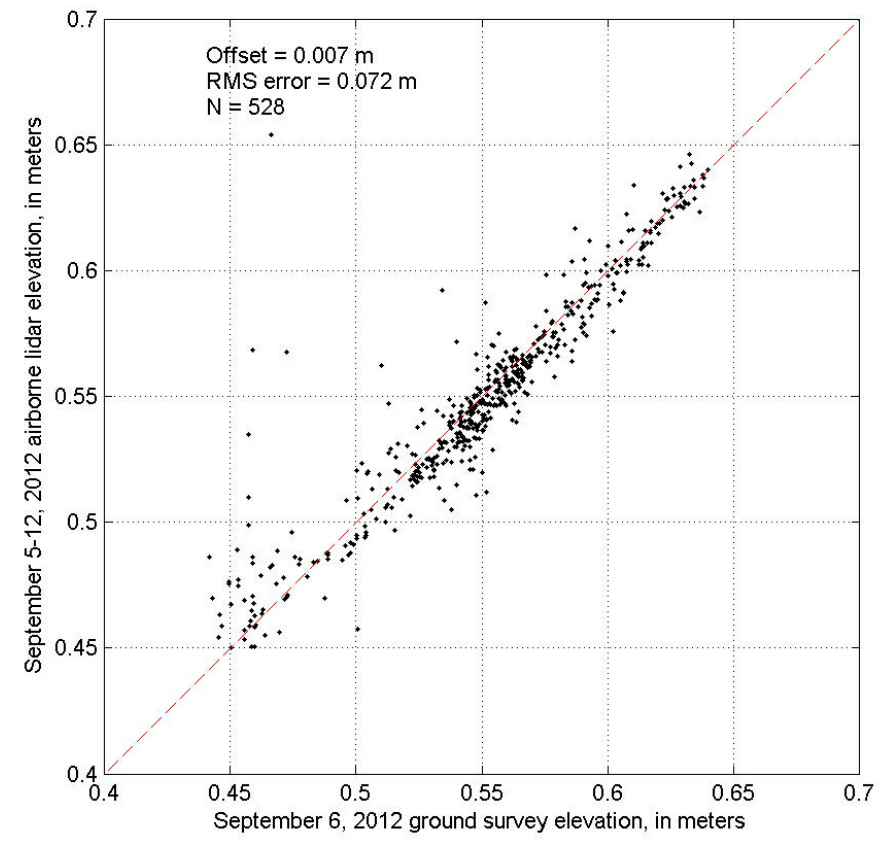

Figure 6. Relation between Chandeleur Islands, Louisiana, ground survey and September 2012 last-return airborne lidar survey.

\subsection{Photo Comparison Analysis}

\subsubsection{Dauphin Island, Alabama}

Dauphin Island, Alabama, has suffered repeated impacts from hurricanes and tropical storms over the last decade. In September 2004, Hurricane Ivan came ashore near Gulf Shores, Alabama, as a Category 3 storm. The hurricane overwashed much of the island, transporting large amounts of sand landward, and cut breaches across the central part of the island. In August 2005, Hurricane Katrina made landfall as a Category 3 storm west of Dauphin Island near the Louisiana-Mississippi border. During Katrina, Dauphin Island suffered extensive overwashing and erosion. The breach caused by Ivan the year before widened and has since become known as Katrina Cut. In 2008, Hurricanes Gustav and Ike eroded the shoreline and, although not impacting the height of the natural dunes, destroyed a 3-m tall, 5.6-km long emergency berm that had been constructed on the beach in early 2007. In November 2009, Hurricane Ida made landfall on Dauphin Island as an extratropical storm (Saint Petersburg Coastal and Marine Science Center, 2013). In addition to the emergency berm built in 2007, a second major structure, a rock wall across Katrina Cut, was built in 2010 in response to the Deepwater Horizon oil spill.

Dauphin Island lay in the path of Isaac's right-front quadrant where the winds were the strongest and directed onshore. The storm surge and superimposed waves overwashed and inundated the island, depositing sand on and landward of the island. The storm caused extensive overwashing near both ends of the rock wall and cut a new breach near the west end of the rock wall.

Figure 7 shows the camera location of pre-storm and post-storm photo-pairs (figs. 8-10) that show some of Isaac's impact on Dauphin Island. The photographs were taken August 8, 2012, 20 days prior to the storm, and September 2, 2012, 5 days after the storm. Additional photo-pairs can be found online at http://coastal.er.usgs.gov/hurricanes/isaac/photo-comparisons/. 


\subsubsection{Chandeleur Islands, Louisiana}

The Chandeleur Islands form the eastern flank of Louisiana and have historically eroded landward at an average of about 9 meters per year ( $\mathrm{m} / \mathrm{yr}$ ) (Penland and others, 2003). The islands have been breached by past hurricanes, such as Camille in 1969, and then recovered to some extent after each storm, with breaches closing naturally. During Hurricane Katrina (August 2005), however, the island lost most of its surface area in just a few hours. Although some natural recovery has been evident in the 8 years since Katrina, a succession of storm activity has eroded the islands at a rapid rate.

In September 2008, waves from Hurricane Gustav overwashed the beaches and dunes, depositing sand on and landward of the islands and eroding the marsh platforms that serve as the islands' foundations. In November 2009, Hurricane Ida passed over the islands as a tropical storm (Saint Petersburg Coastal and Marine Science Center, 2013). In 2010, a large sand berm was constructed, partly on and partly seaward of the islands, in response to the Deepwater Horizon oil spill. A portion of the berm can be seen in the pre-storm photograph in figure 11. Tropical Storm Lee tracked north of the Chandeleur Islands in September 2011, causing a large portion of the oil-protection berm to disintegrate (Plant and Guy, 2013a,b).

Hurricane Isaac's large size and slow speed as it approached the coast allowed it to impact the coast over many hours. Like Dauphin Island, the Chandeleur Islands lay in the path of the storm's rightfront quadrant where the winds were the strongest and onshore. Storm surge and superimposed waves once again inundated and overwashed the beaches. Sand was deposited on and landward of the islands, and the marsh platforms were eroded.
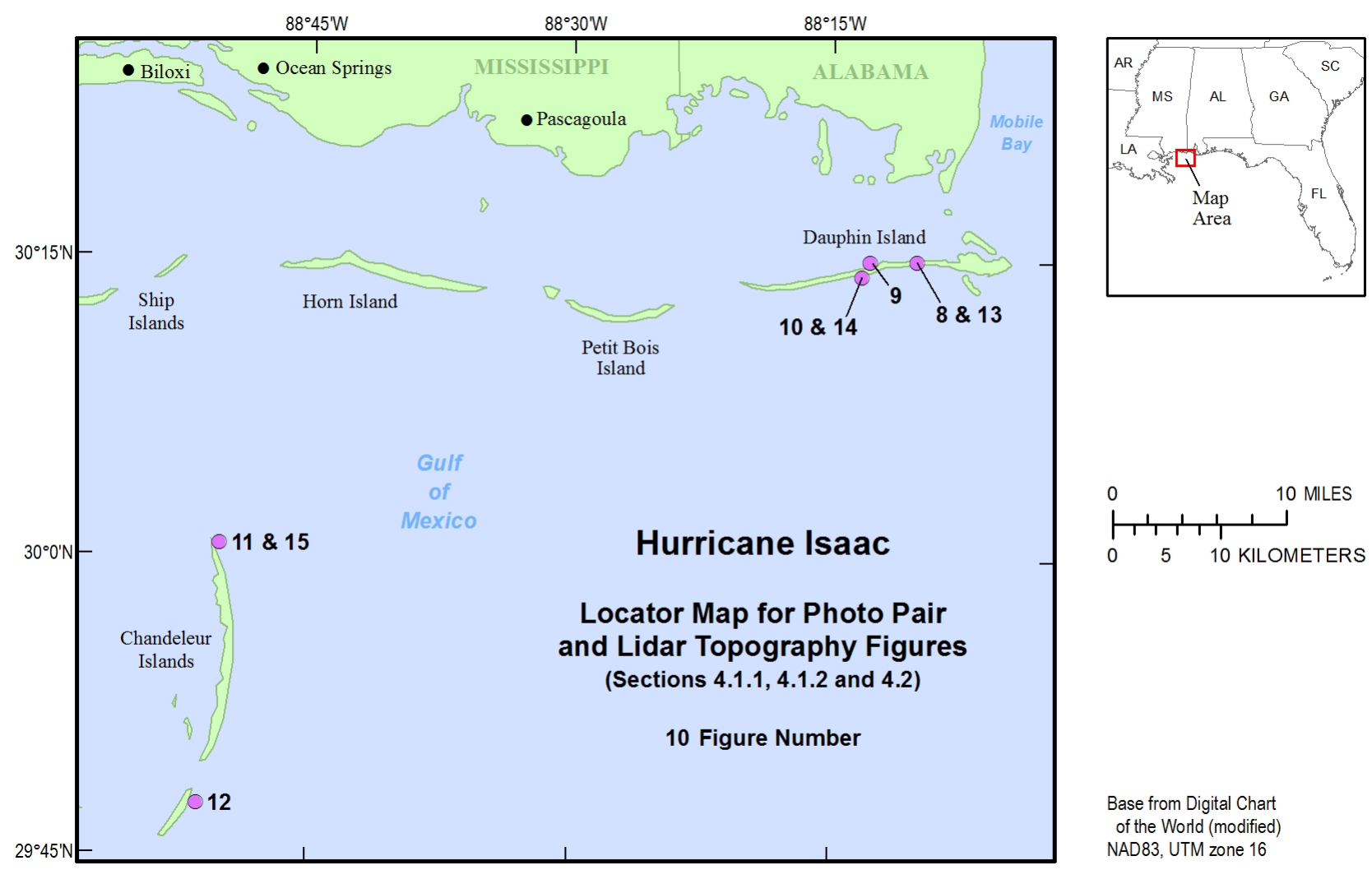

Figure 7. Map showing locations of photo-pair and lidar topography figures found in sections 4.1.1, 4.1.2, and 4.2. 

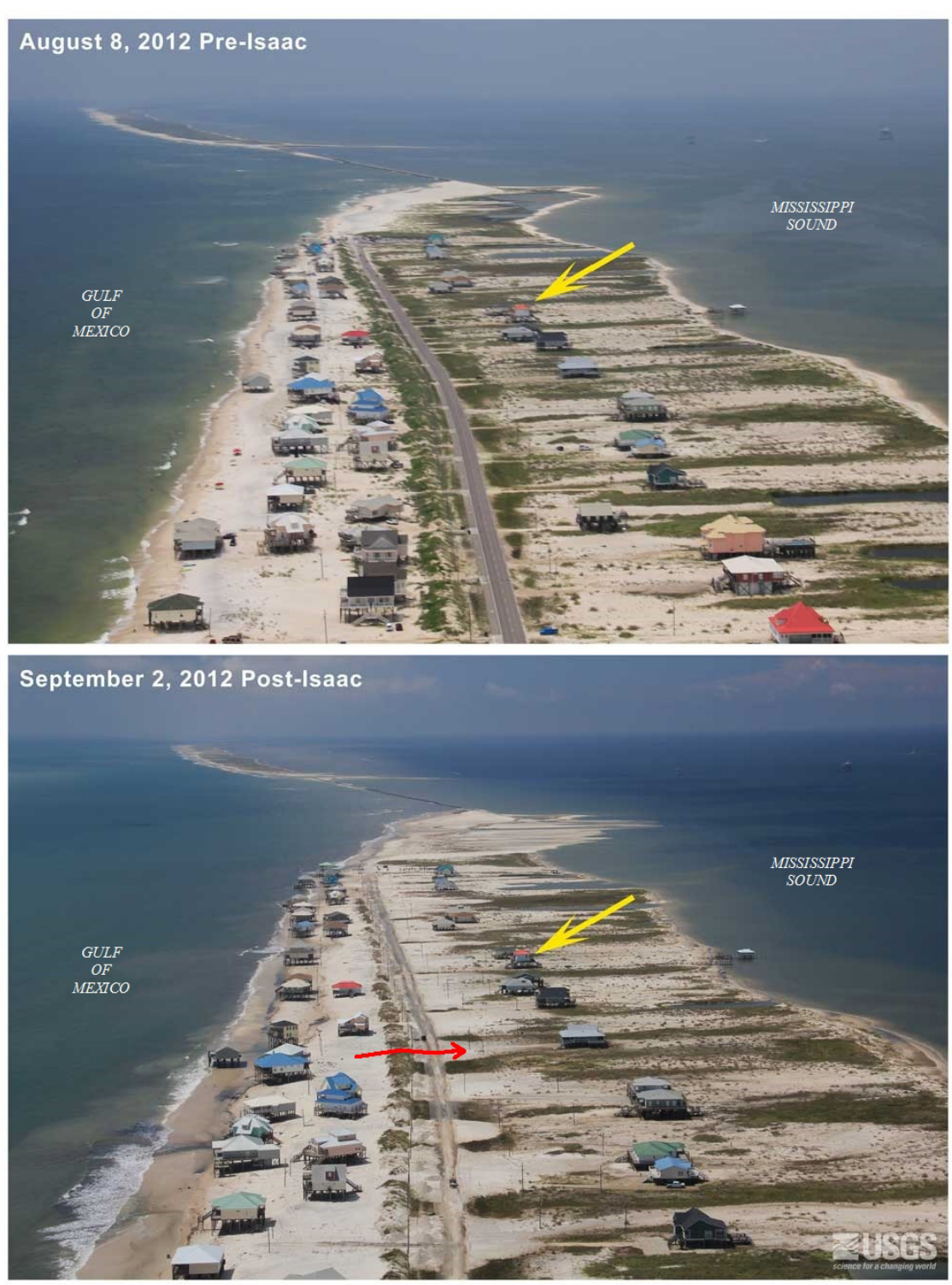

Figure 8. Oblique aerial photographs of Dauphin Island, Alabama, from August 8, 2012 (top) and September 2, 2012 (bottom), 5 days after Hurricane Isaac made landfall. The view is looking west along the island with the Gulf of Mexico on the left and the Mississippi Sound on the right. The yellow arrows in each photograph point to the same feature. Overwash from the Gulf (left) deposited sand onto the road and beyond. It appears that the overwash funneled through breaks in dunes that were constructed in 2010 in response to the Deepwater Horizon oil spill as illustrated by the red arrow. The inlet seen in the distance (Katrina Cut) started as an island breach made by Hurricane Ivan in 2004. Hurricane Katrina widened the breach into an inlet in 2005. The linear rock structure spanning the inlet was built in 2010 in response to the Deepwater Horizon oil spill.

Figures 11-12 are pre-storm and post-storm photo-pairs that show some of the effects of Isaac on the islands. The photographs were taken August 8, 2012, 20 days prior to the storm, and September 2, 2012, 5 days after the storm. The point-of-view locations of the photo-pairs are shown in figure 7 . Additional photo-pairs can be found online at http://coastal.er.usgs.gov/hurricanes/isaac/photo-comparisons/.

\subsection{Pre-Storm and Post-Storm Lidar Topography}

The post-Isaac lidar survey of the Louisiana, Mississippi, and Alabama barrier islands was flown September 5-10, 2012, to measure coastal topography. To determine the change in elevation caused by Hurricane Isaac, a January 2010 lidar survey was used for the pre-Isaac elevations in Dauphin Island, Alabama, and a February 2012 lidar survey was used for the Chandeleur Islands, Louisiana. Comparing pre- and post-storm elevations reveals areas of beach erosion, overwash deposition, and island breaching and allows characterization of the nature, magnitude, and spatial variability of hurricane-induced coastal change. 

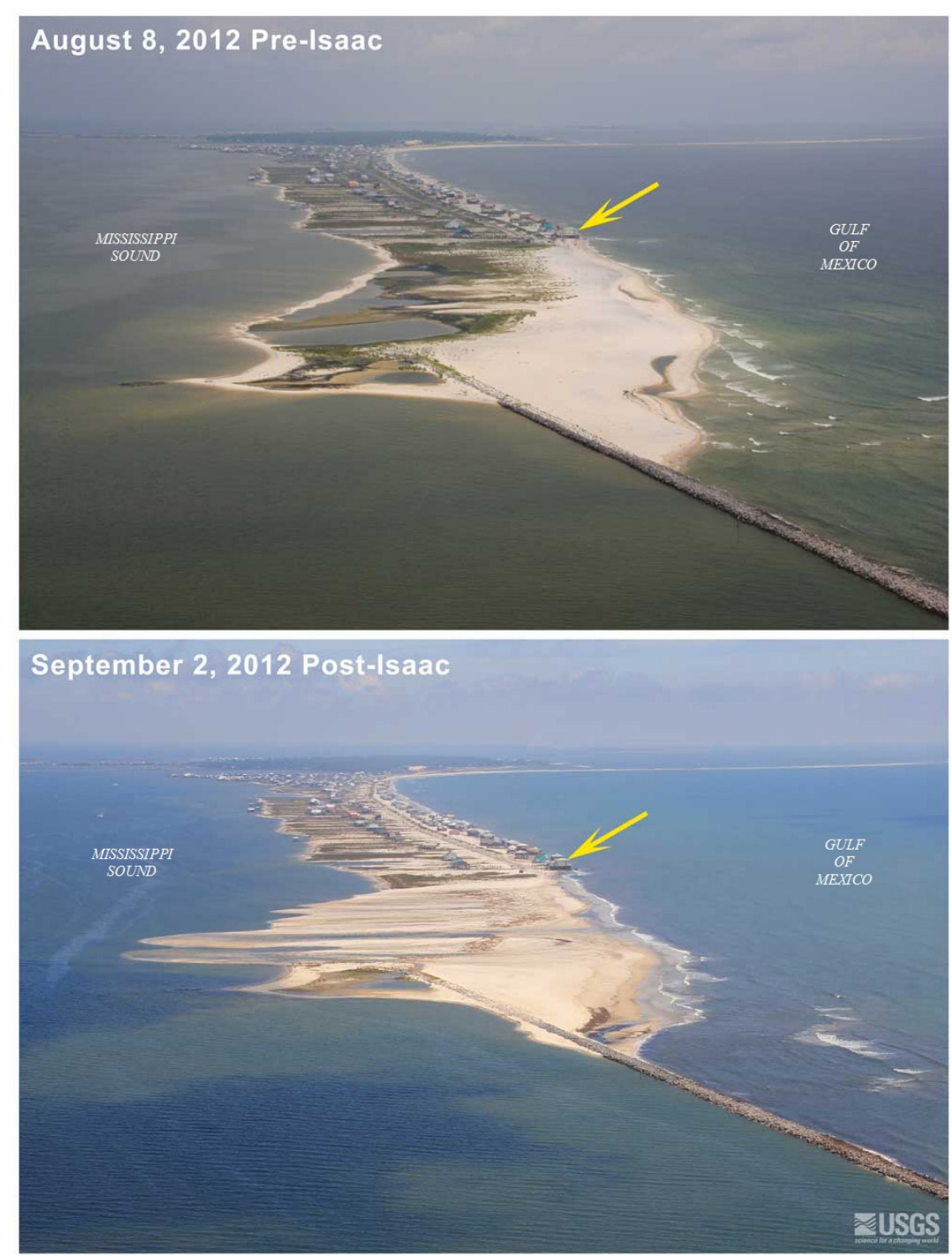

Figure 9. Oblique aerial photographs of Dauphin Island, Alabama, from August 8, 2012 (top) and September 2, 2012 (bottom), 5 days after Hurricane Isaac made landfall. The view is looking from Katrina Cut east along the island with the Gulf of Mexico on the right and the Mississippi Sound on the left. The yellow arrows in each photograph point to the same feature. Overwash crossed the width of the island, filling water bodies with sand and depositing more sand into the sound.

Figures 13-15 show some of the coastal changes that occurred on Dauphin Island, Alabama, and Chandeleur Islands, Louisiana, during Hurricane Isaac. Each figure includes pre-storm and post-storm elevation maps and an elevation change map. In the elevation maps, yellow and green colors indicate lower elevations, and orange and red colors indicate higher elevations. In the elevation change maps, the yellow to red colors indicate erosion (such as shoreline retreat), and blue to green colors indicate accretion (such as overwash deposits where waves and surge have moved sand landward). The locations of the figures are shown in figure 7.

\subsection{Coastal Change Analysis}

A pre-Isaac lidar survey conducted September 5-8, 2008 covered the entire extent of the study area and was used with the post-Isaac survey to quantify the changes Hurricane Isaac made to beach and dune morphology. Although there are more-recent lidar data in some regions, using the 2008 pre-storm data allows a consistent treatment of changes occurring over a common time interval. The last-return lidar data were gridded to quantify change in the height and elevation of the frontal sand dune or berm 

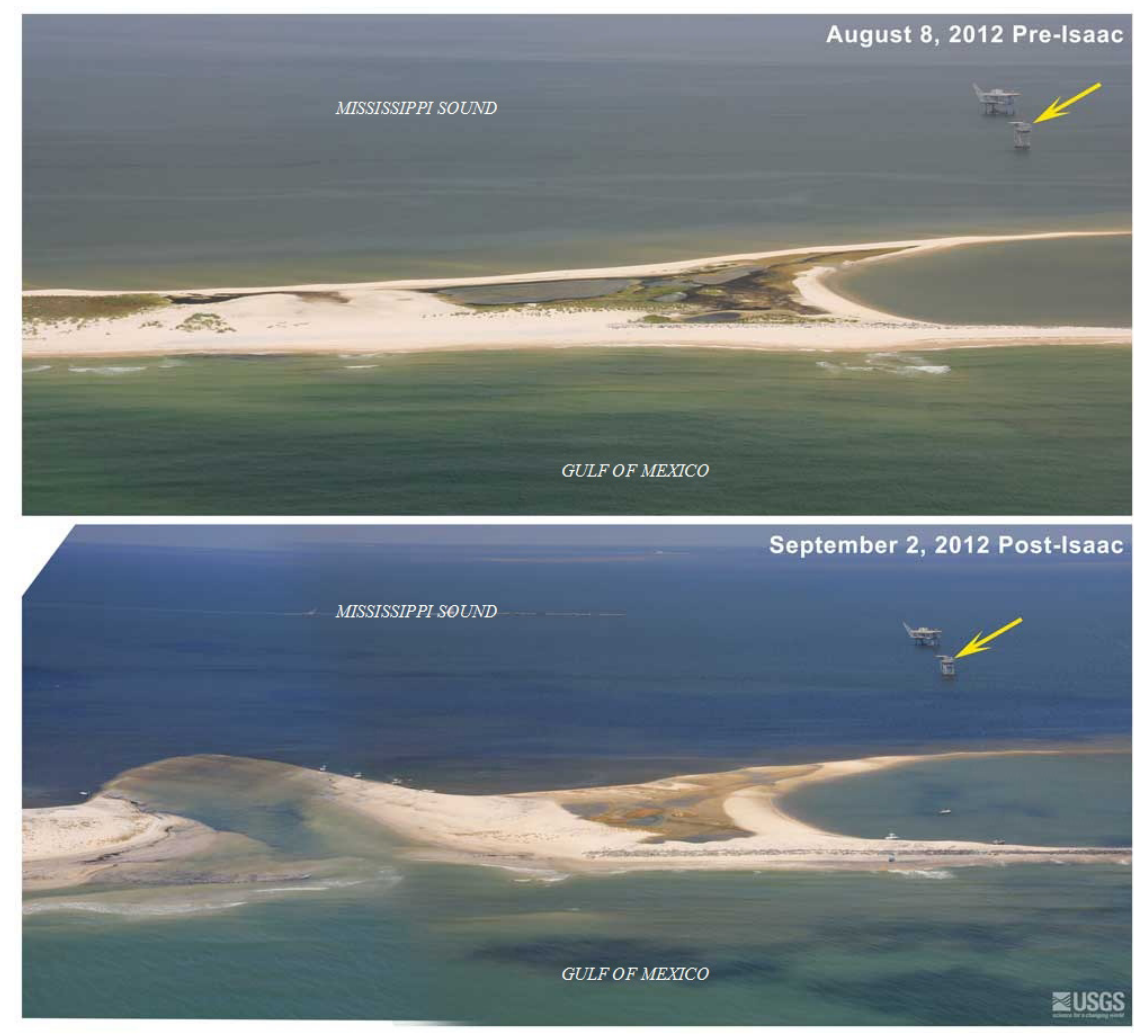

Figure 10. Oblique aerial photographs of Dauphin Island, Alabama, from August 8, 2012 (top) and September 2, 2012 (bottom), 5 days after Hurricane Isaac made landfall. The view is looking northward from the Gulf of Mexico to the island immediately west of Katrina Cut and beyond to the Mississippi Sound. The yellow arrows in each photograph point to the same feature. Storm surge and wave setup and runup cut through the island, creating a new breach and depositing sand into the sound in the form of an overwash fan.

system, change in shoreline position, and change in beach volume. A resolution of $10 \mathrm{~m}$ in the alongshore direction and $2.5 \mathrm{~m}$ in the cross-shore direction was used. The data were spatially filtered using a Hanning window twice the grid resolution (Plant and others, 2002), and the grids were rotated to parallel the shoreline.

The cross-shore peak elevations of the most seaward sand dune (or berm if there was no dune) were found and their locations extracted from the grids at $10 \mathrm{~m}$ intervals in the alongshore direction. The pre-storm to post-storm difference in elevation at those locations was defined as hurricane-induced change (figs. 16A-18A) (Stockdon and others, 2009).

The shoreline position was extracted from the grids at $10 \mathrm{~m}$ intervals in the alongshore direction by locating the cross-shore position of the mean high water (MHW) elevation. The MHW elevation was based on regional tidal records (Weber and others, 2005). A MHW elevation of $0.37 \mathrm{~m}$ NAVD 88 was used for the region from Isles Dernieres to Pelican Island, Louisiana, and $0.23 \mathrm{~m}$ was used for the Chandeleur Islands, Louisiana, and the Mississippi and Alabama barrier islands region. Shoreline change was calculated by measuring the cross-shore distance between the pre-storm and post-storm shoreline position (figs. 16B-18B). Shoreline position errors are typically on the order of 1 to $2 \mathrm{~m}$ (Stockdon and others, 2002) with varying uncertainty due to data noise and beach slope.

Beach volume changes were calculated at $10 \mathrm{~m}$ intervals in the alongshore direction by differencing the pre-storm and post-storm elevation grids and integrating the differenced values in the crossshore direction that fell between the pre-storm shoreline and pre-storm dune base, yielding the volume change per meter length of coastline (figs. 16C-18C). 


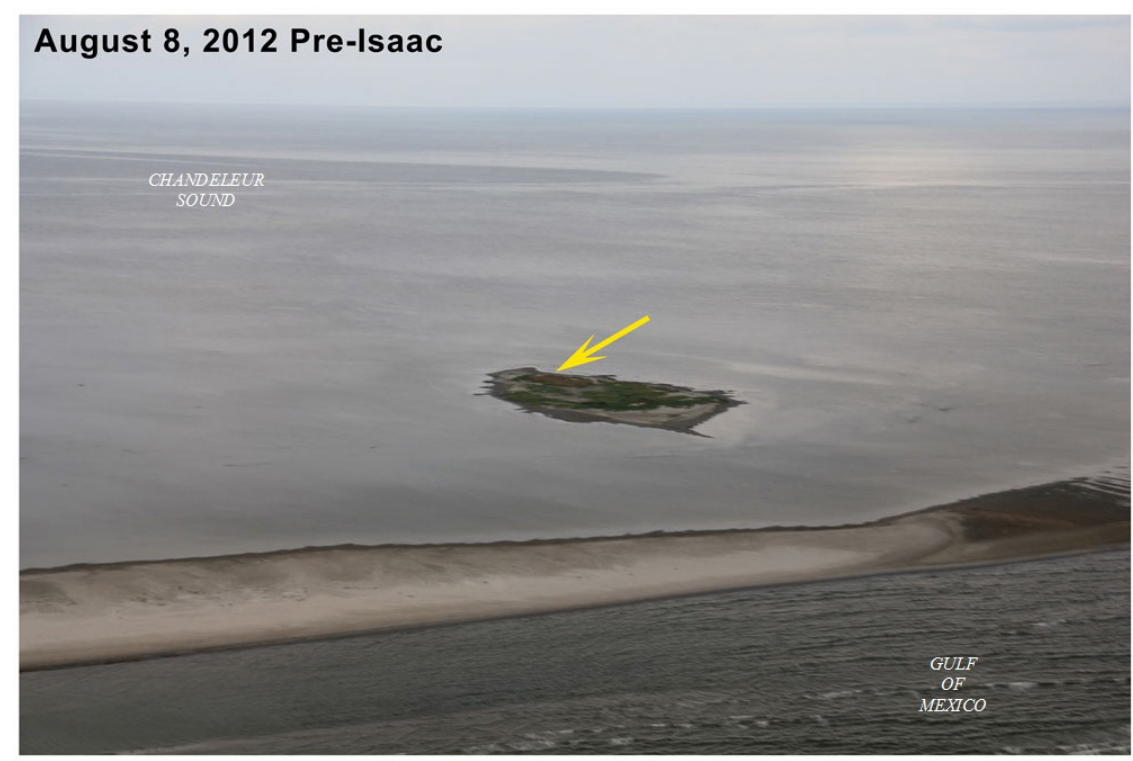

September 2, 2012 Post-Isaac

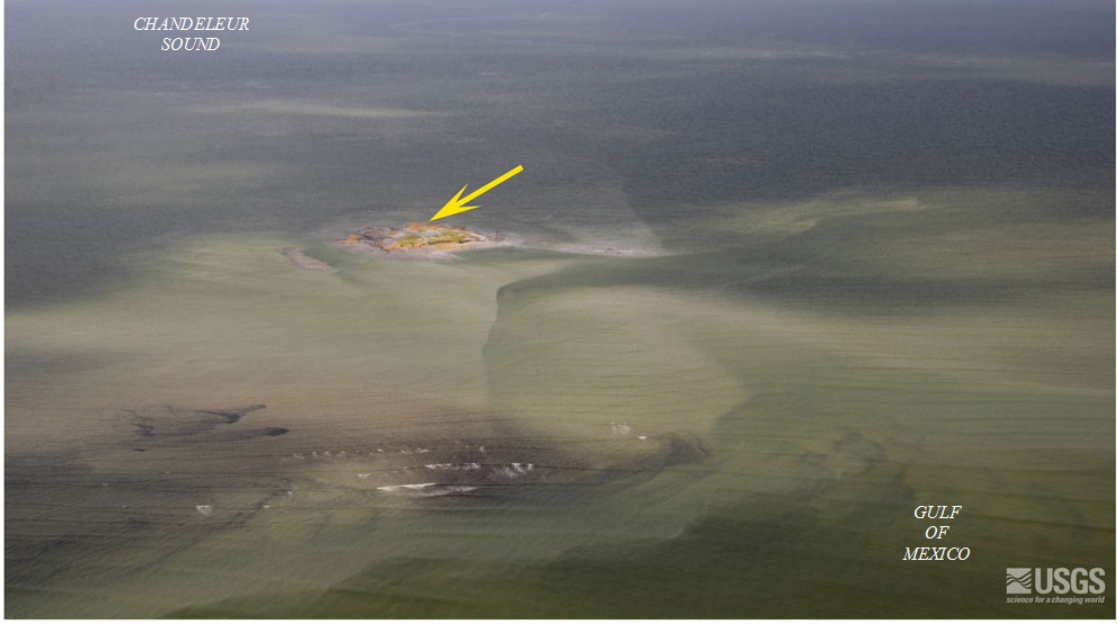

Figure 11. Oblique aerial photographs of a remnant of Chandeleur Islands, Louisiana, from August 8, 2012 (top) and September 2, 2012 (bottom), 5 days after Hurricane Isaac made landfall. The view is looking west from the Gulf of Mexico to Chandeleur Sound. The yellow arrows in each photograph point to the same feature. The sand in the pre-storm photograph is part of an oil-protection berm that was constructed in response to the 2010 Deepwater Horizon oil spill. The berm was completely eroded away by Isaac and the sand was distributed into the surrounding waters.

\subsubsection{Barrier Island Coast of Central Louisiana}

A reduction in dune height ranging from 0 to $3 \mathrm{~m}$ was observed in the Isles Dernieres, Louisiana, and near Port Fourchon, Louisiana, where Hurricane Isaac made landfall. Dune-height changes were positive at Grand Isle, Louisiana, about $20 \mathrm{~km}$ to the east of landfall, due to construction of a manmade line of dunes in 2009 (Cardno, 2009) (U. S. Army Corps of Engineers, 2012) (fig. 16A). Shoreline change was variable on the central Louisiana coast from Trinity Island (part of the Isles Dernieres) to Grand Isle, Louisiana. Shoreline accretion eastward of the Grand Isle line is likely due to beach nourishment projects (Coastal Protection and Restoration Authority, 2013) evident in aerial photography (GoogleEarth, 2013) (fig. 16B). On the eastern and western ends of the Isles Dernieres, where currents flowing through inlets rapidly move sand, more extreme shoreline erosion and accretion of 100 to $200 \mathrm{~m}$ was observed. Volume changes largely follow the same pattern as the shoreline changes for the central Louisiana barrier islands (fig. 16C). The large volume gain to the west of Port Fourchon was the result of a restoration project in July 2012 (Scofield, 2012). 


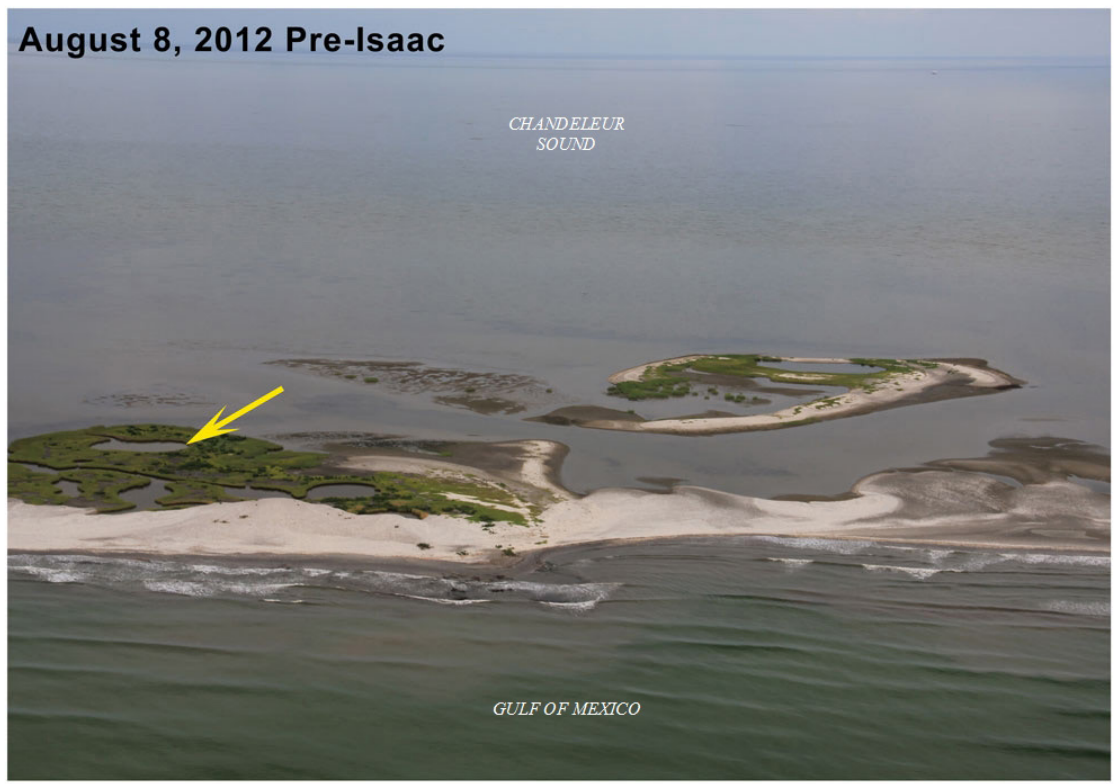

September 2, 2012 Post-Isaac

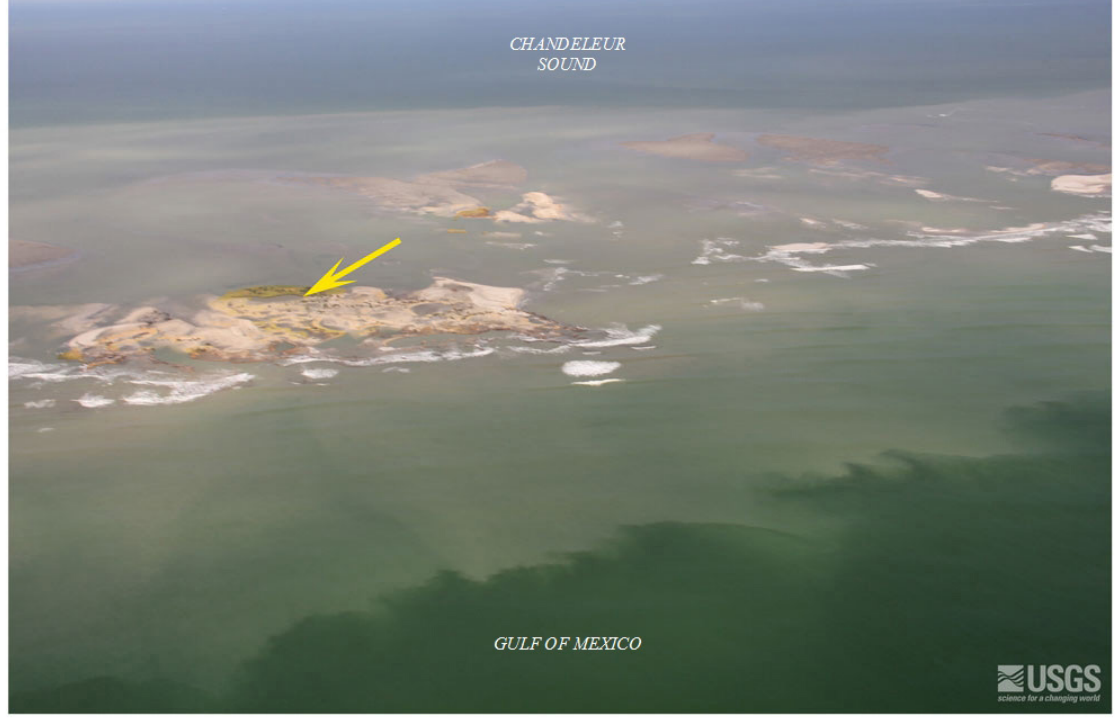

Figure 12. Oblique aerial photographs of Chandeleur Islands, Louisiana, from August 8, 2012 (top) and September 2, 2012 (bottom), 5 days after Hurricane Isaac made landfall. The view is looking west from the Gulf of Mexico, across the island and beyond to Chandeleur Sound. The yellow arrows in each photograph point to the same feature. The island was severely eroded by waves and storm surge. Sand was deposited on the island remnants and into the sound.

\subsubsection{Mississippi Barrier Island Coast}

Along the Mississippi barrier island coast, 150 to $200 \mathrm{~km}$ to the east of where Hurricane Isaac made landfall, dune-height erosion ranged from 0 to $3 \mathrm{~m}$ (fig. 17A). The eastern ends of West Ship, Horn, and Petit Bois Islands all experienced dune erosion of 2 to $3 \mathrm{~m}$, while the western ends of the islands had little change, possibly due to the long-term westward migration of the islands. Shoreline erosion of 40 to $50 \mathrm{~m}$ was observed across the region, with the exception of an accretion of about $100 \mathrm{~m}$ near the center of Horn Island where there is an inflection point in the shoreline orientation (fig. 17B). Similar to the Louisiana sandy barriers, volume losses here follow the same pattern as shoreline changes (fig. 17C). Because the pre-storm survey is from September 2008, changes in shoreline position and beach volume presented here may be a combination of long-term and storm-induced change. 

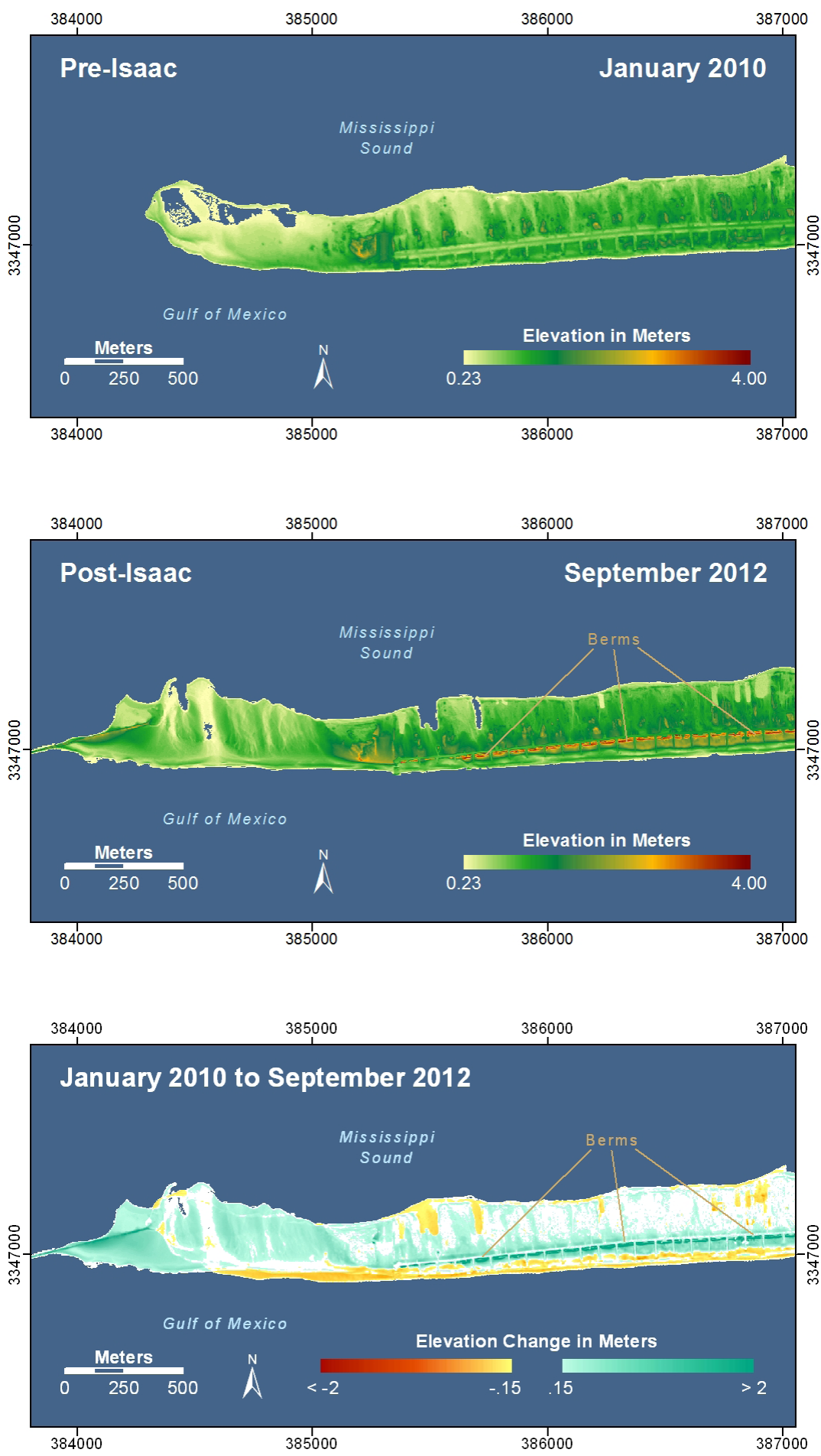

Figure 13. Elevation of Dauphin Island, Alabama, before (top) and after (middle) Hurricane Isaac and elevation change (bottom). The western extent of the inhabited portion of Dauphin Island (east of Katrina Cut) experienced shoreline erosion and overwash. In the post-storm elevation map, a line of berms running west-east along the road form higher elevation features that were not present in the pre-storm elevation map and appear as regions of deposition in the elevation difference map. These berms were constructed in response to the 2010 Deepwater Horizon oil spill after the pre-storm lidar data were collected and prior to Isaac's landfall. Overwash deposition appears north of the main access road. The deposition at the western end of the map documents the construction of the rock structure placed across Katrina Cut. Houses were removed from the lidar data and are not represented in these maps. 


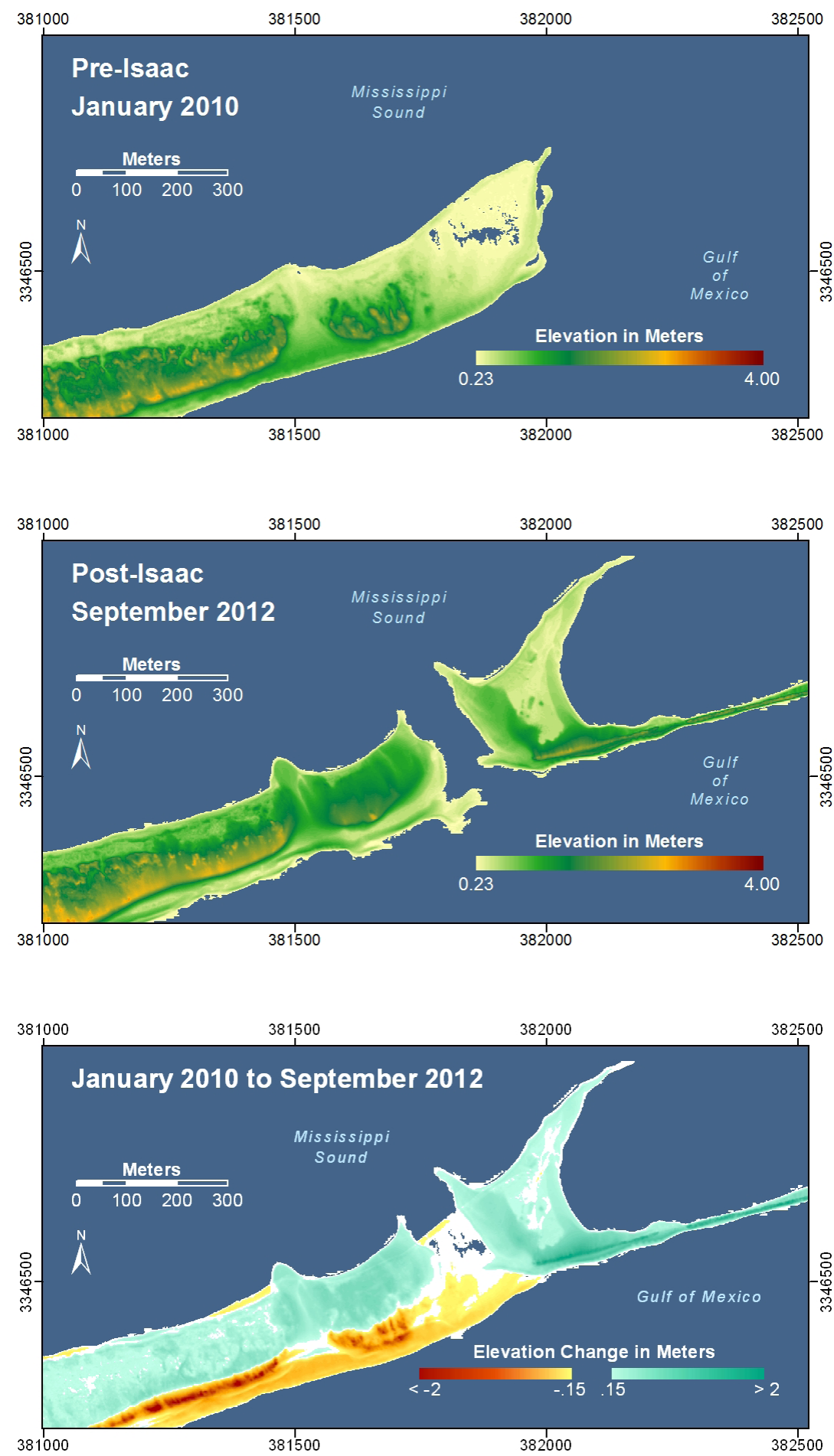

Figure 14. Elevation of Dauphin Island, Alabama, west of Katrina Cut, before (top) and after (middle) Hurricane Isaac and elevation change (bottom). The inlet that formed during Hurricane Katrina was closed with a rock structure (figs. 8-10) after collection of the prestorm lidar data and prior to Isaac's landfall and appears as a depositional feature in the bottom map. During Isaac, the island to the west of the rock structure was breached and experienced shoreline erosion and overwash. The spit feature behind the rock structure formed prior to Hurricane Isaac. 

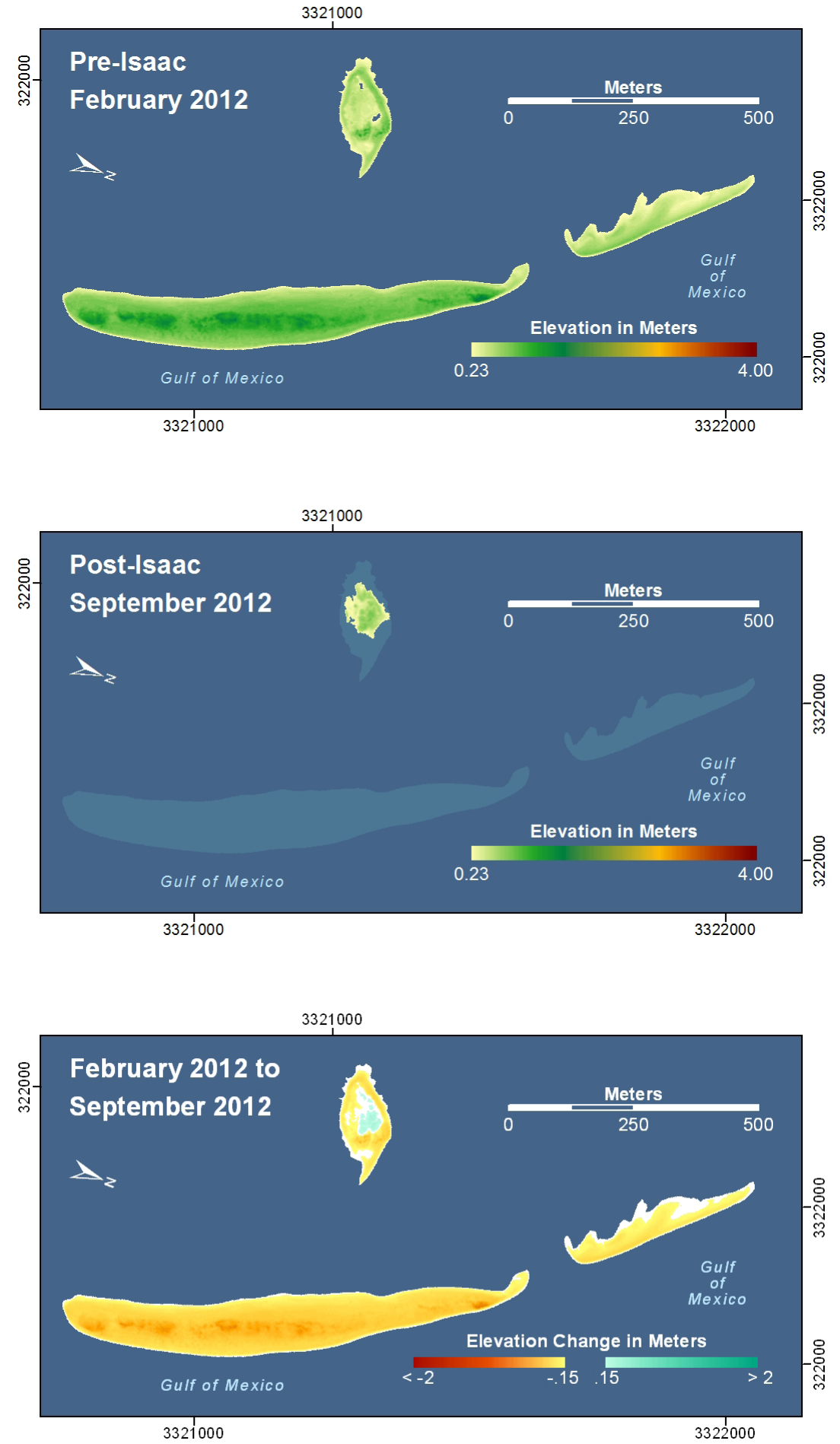

Figure 15. Elevation of Chandeleur Islands, Louisiana, before (top) and after (middle) Hurricane Isaac and elevation change (bottom). In 2010, a sand berm was constructed seaward of a small, remnant island at the north end of the islands. Prior to Hurricane Isaac, the berm had been eroded, but some sections still remained. Storm surge and waves from Isaac eroded away what remained of the berm. The remnant island experienced erosion along its outer edge and some deposition occurred in the island center. In the post-Isaac (middle) map, the prestorm berm and island footprints are indicated in light blue. 

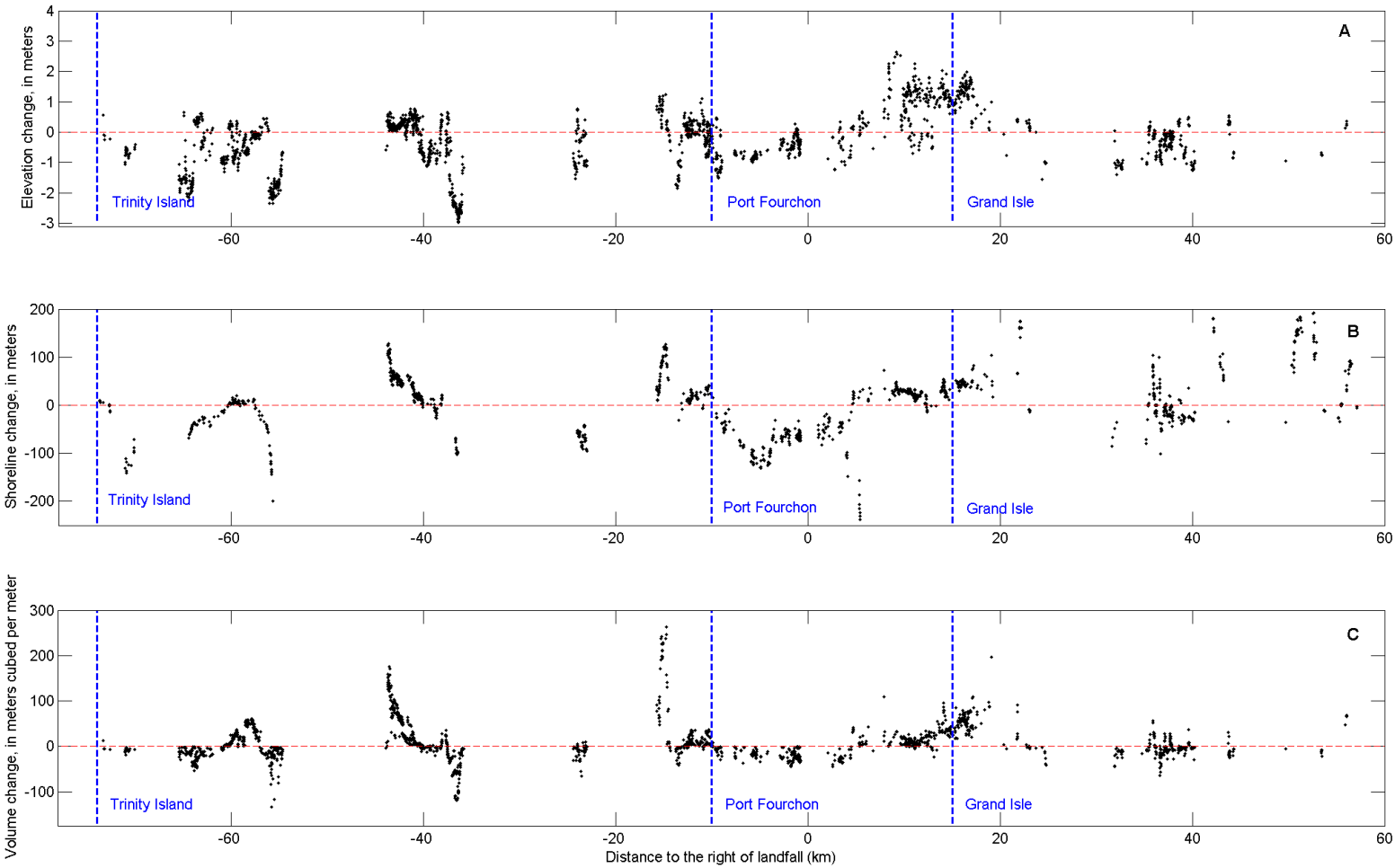

Figure 16. Hurricane Isaac (A) dune elevation change, (B) shoreline change, and (C) beach volume change between September 2008 and September 2012 for the central Louisiana barrier island coast. Vertical dashed lines indicate the center of Trinity Island (the easternmost of the three islands composing the Isles Dernieres), and the towns of Port Fourchon and Grand Isle, Louisiana. In the x-axis label, "right" refers to the right side of the forward path of the hurricane, or "east" here.
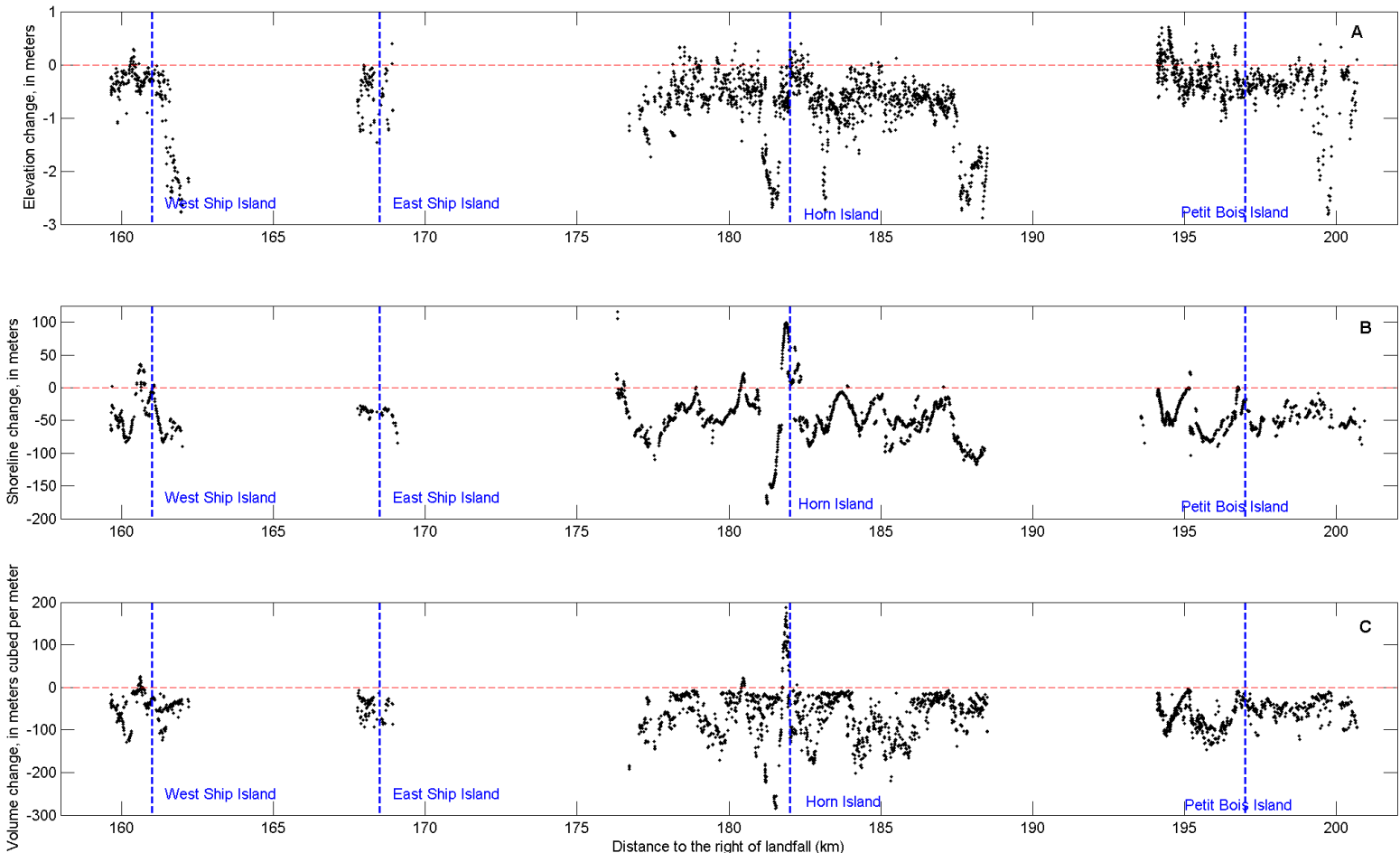

Figure 17. Hurricane Isaac (A) dune elevation change, (B) shoreline change, and (C) beach volume change between September 2008 and September 2012 for the state of Mississippi barrier island coast. Vertical dashed lines indicate the centers of West and East Ship Islands, Horn Island, and Petit Bois Island. In the x-axis label, "right" refers to the right side of the forward path of the hurricane, or "east" here. 


\subsubsection{Dauphin Island, Alabama}

Dauphin Island, Alabama, $220 \mathrm{~km}$ to the east of where Hurricane Isaac made landfall, experienced very little change from the pre-storm dune height (fig. 18A). Some dunes to the west of the Katrina Cut were overwashed during Hurricane Isaac, resulting in 2 to $3 \mathrm{~m}$ of dune erosion. Shoreline change was variable, particularly on the west side of the island where $1 \mathrm{~km}$-long oscillations were apparent (fig. 18B). The beach on the western edge of Katrina Cut experienced 100-150 m of shoreline loss and corresponding volume loss. The area of shoreline accretion on the eastern side of the island corresponds to the continued northeast migration of Pelican Island shoal. Volume changes mirror the same pattern as the shoreline changes for the Dauphin Island coast, with losses greatest to the west of Katrina Cut and the largest gain near the pier (approximately $225 \mathrm{~km}$ to the east of where Isaac made landfall) (fig. 18C).
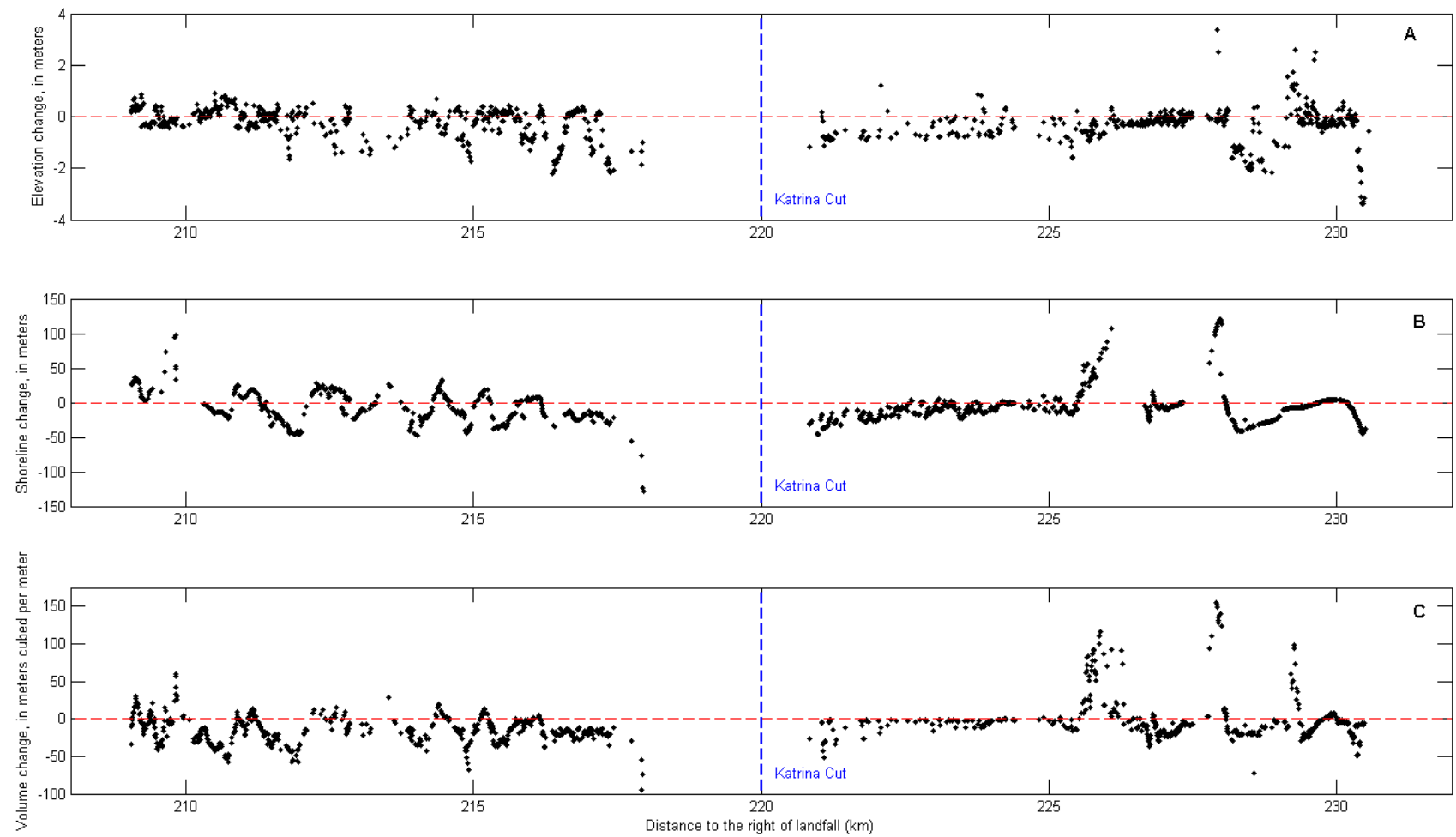

Figure 18. Hurricane Isaac (A) dune elevation change, (B) shoreline change, and (C) beach volume change between September 2008 and September 2012 for Dauphin Island. In the x-axis label, "right" refers to the right side of the forward path of the hurricane, or "east" here. 


\section{References}

Berg, R., 2013, Tropical Cyclone Report Hurricane Isaac: National Oceanic and Atmospheric Administration National Hurricane Center Report AL092012, 78 p.

Bonisteel, J.M., Nayegandhi, Amar, Wright, C.W., Brock, J.C., and Nagle, D.B., 2009, Experimental Advanced Airborne Research Lidar (EAARL) data processing manual: U.S. Geological Survey OpenFile Report 2009-1078, 38 p.

Brock, J.C., Wright, C.W., Sallenger, A.H., Krabill, W.B., and Swift, R.N., 2002, Basis and methods of NASA airborne topographic mapper lidar surveys for coastal studies: Journal of Coastal Research, v. 18 , no. 1, p. $1-13$.

Cardno, C.A., 2009, Geotube reinforced sand dunes to buffer Louisiana barrier island from hurricanes: Civil Engineering, v. 10, p. 20-21.

Coastal Protection and Restoration Authority, 2013, Projects web page, accessed October 30, 2013, at http://coastal.la.gov/our-work/projects/.

Fanelli, Paul, and Wolcott, David, 2012, NOAA NOS water level and meteorological data report Hurricane Isaac, p. 46, accessed October 24, 2013, at http://tidesandcurrents.noaa.gov/publications/ Hurricane Isaac 2012 Water_Level and_Meteorological Data_Report.pdf.

GoogleEarth, 2013, Grand Terre Island to Pelican Island, Louisiana (lower left $89.95^{\circ} \mathrm{W}, 29.19^{\circ} \mathrm{N}$; upper right $89.44^{\circ} \mathrm{W}, 29.33^{\circ} \mathrm{N}$ ): U.S. Geological Survey, U.S. Department of Agriculture, National Aeronautics and Space Administration, and DigitalGlobe imagery, 2008-2011, accessed July 15, 2013, at http://www.googleearth.com/.

McCallum, B.E., McGee, B.D., Kimbrow, D.R., Runner, M.S., Painter, J.A., Frantz, E.R., and Gotvald, A.J., 2012, Monitoring storm tide and flooding from Hurricane Isaac along the Gulf Coast of the United States, August 2012: U.S. Geological Survey Open-File Report 2012-1263, available online at http://pubs.er.usgs.gov/publication/ofr20121263.

National Geodetic Survey, 2013, Continuously operating reference station (CORS): National Oceanographic and Atmospheric Administration, accessed July 10, 2013, at http://www.ngs.noaa.gov/CORS/.

National Oceanic and Atmospheric Administration, [undated c], National Data Buoy CenterMeteorological/ocean stations 42001, 42012, and 42360: National Oceanic and Atmospheric Administration, accessed July 10, 2013, at http://www.ndbc.noaa.gov/.

Nayegandhi, Amar., Brock, J.C., and Wright, C.W., 2009, Small-footprint, waveform-resolving lidar estimation of submerged and sub-canopy topography in coastal environments: International Journal of Remote Sensing, v. 30, no. 4, p. 861-878.

Penland, Shea, Zganjar, Chris, Westphal, K.A., Connor, Paul, Beall, Andrew, List, Jeff, and Williams, S.J., 2003, Shoreline change posters of the Louisiana Barrier Islands: 1885 to 1996: U.S. Geological Survey Open-File Report 2003-398, 8 sheets.

Plant, N.G., and Guy, K.K., 2013a, Change in the length of the northern section of the Chandeleur Islands oil berm, September 5, 2010, through September 3, 2012: U.S. Geological Survey Open-File Report 2013-1074, available at http://pubs.usgs.gov/of/2013/1074/. 
Plant, N.G., and Guy, K.K., 2013b, Change in the length of the middle section of the Chandeleur Islands oil berm, November 17, 2010, through September 6, 2011: U.S. Geological Survey Open-File Report 2013-1075, available at http://pubs.usgs.gov/of/2013/1075/.

Plant, N.G., Holland, K.T., and Puleo, J.A., 2002, Analysis of the scale of errors in nearshore bathymetric data: Marine Geology, v. 191, no. 1-2, p. 71-86.

Powell, M.D., Houston, S.H., Amat, L.R., and Morisseau-Leroy, N., 1998, The HRD real-time hurricane wind analysis system: Journal of Wind Engineering and Industrial Aerodynamics, v. 77-78, p. 53-64.

Saint Petersburg Coastal and Marine Science Center, 2013, Coastal change hazards: Hurricanes and extreme storms: U S. Geological Survey, available at http://coastal.er.usgs.gov/hurricanes/.

Sallenger, A.H., Krabill, W.B., Swift, R.N., Brock, J., List, J., Hansen, Mark, Holman, R.A., Manizade, S., Sontag, J., Meredith, A., Morgan, K., Yunkel, J.K., Frederick, E.B., and Stockdon, H.F., 2003, Evaluation of airborne topographic lidar for quantifying beach changes: Journal of Coastal Research, v. 19 , no. 1, p. $125-133$.

Schott, T., Landsea, C., Hafele, G., Lorens, J., Taylor, A., Thurm, H., Ward, B., Willis, M., and Zaleski, W., 2012, The Saffir-Simpson hurricane wind scale, updated 1 February 2012: National Oceanographic and Atmospheric Administration, National Hurricane Center report available at http://www.nhc.noaa.gov/pdf/sshws.pdf.

Scofield, C., 2012, Restoration projects will protect Port Fourchon, Fox 8, WVUE Web page, accessed June 17, 2012, at http://www.fox8live.com/story/19004682/restoration-projects-will-protect-port-fourchon.

Stockdon, H., Sallenger, A., List, J., and Holman, R., 2002, Estimation of shoreline position and change using airborne topographic lidar data: Journal of Coastal Research, v. 18, no. 3, p. 502-513.

Stockdon, H.F., Doran, K.S., and Sallenger, A.H., 2009, Extraction of lidar-based dune-crest elevations for use in examining the vulnerability of beaches to inundation during hurricanes: Journal of Coastal Research Special Issue 53 (Fall 2009), p. 59-65.

Stockdon, H.F., Sallenger, A.H., Jr., Holman, R., and Howd, P., 2007, A simple model for the spatiallyvariable coastal response to hurricanes: Marine Geology, v. 238, p. 1-20.

U.S. Army Corps of Engineers, 2012, Grand Isle fact sheet, updated August 2012, available at http://www.mvn.usace.army.mil/Portals/56/docs/PAO/FactSheets/GrandIsle.pdf.

Weber, K.M., List, J.H., and Morgan, K.L.M., 2005, An operational mean high water datum for determination of shoreline position from topographic lidar data: U.S. Geological Survey Open-File Report 2005-1027, available at http://pubs.usgs.gov/of/2005/1027/. 